\title{
Impairment Mechanisms and Intervention Approaches for Aged Human Neuromuscular Junctions
}

\author{
Yomna Badawi ${ }^{1}$ and Hiroshi Nishimune ${ }^{1,2 *}$ \\ ${ }^{1}$ Department of Anatomy and Cell Biology, University of Kansas School of Medicine, Kansas City, KS, United States, \\ ${ }^{2}$ Neurobiology of Aging, Tokyo Metropolitan Institute of Gerontology, Itabashi, Japan
}

\section{OPEN ACCESS}

Edited by:

Hanns Lochmuller,

University of Ottawa, Canada

Reviewed by:

Clarke Slater

Retired, Newcastle upon Tyne, United

Kingdom

Robert W. Burgess,

Jackson Laboratory, United States

Rüdiger Rudolf,

Mannheim University of Applied

Sciences, Germany

*Correspondence:

Hiroshi Nishimune

nishimun@tmig.or.jp

Received: 01 June 2020

Accepted: 16 October 2020

Published: 16 November 2020

Citation:

Badawi Y and Nishimune H (2020)

Impairment Mechanisms

and Intervention Approaches for Aged

Human Neuromuscular Junctions.

Front. Mol. Neurosci. 13:568426.

doi: $10.3389 /$ fnmol.2020.568426
The neuromuscular junction (NMJ) is a chemical synapse formed between a presynaptic motor neuron and a postsynaptic muscle cell. NMJs in most vertebrate species share many essential features; however, some differences distinguish human NMJs from others. This review will describe the pre- and postsynaptic structures of human NMJs and compare them to NMJs of laboratory animals. We will focus on age-dependent declines in function and changes in the structure of human NMJs. Furthermore, we will describe insights into the aging process revealed from mouse models of accelerated aging. In addition, we will compare aging phenotypes to other human pathologies that cause impairments of pre- and postsynaptic structures at NMJs. Finally, we will discuss potential intervention approaches for attenuating age-related NMJ dysfunction and sarcopenia in humans.

Keywords: active zone (AZ), aging, caloric restriction, exercise, laminin, neuromuscular disease, progeria, synapse

\section{INTRODUCTION}

Synapses are required to maintain the proper function of the nervous system both in health and during disease. The neuromuscular junction (NMJ) is a synapse critical for the transfer of information between a presynaptic motor neuron and a postsynaptic muscle fiber at specialized sites on the muscle plasma membrane called endplates. During development, motor neurons seek out and find nascent endplates on the sarcolemmal surface (skeletal muscle fiber plasma membrane) (Frank and Fischbach, 1979; Sanes and Lichtman, 2001). Innervation of muscle fibers by motor neurons ensures proper control of skeletal muscle contraction through the regulated release of neurotransmitters. Among vertebrate NMJs, the neurotransmitter acetylcholine (ACh) is released from highly specialized sites at the presynaptic membrane called active zones. By electron microscopy analysis, active zones appear as electron-dense projections on the presynaptic membrane where synaptic vesicles fuse for subsequent exocytosis (Couteaux and Pecot-Dechavassine, 1970; Tsuji, 2006). In human NMJs, freeze-fracture electron microscopy shows

Abbreviations: ACh, acetylcholine; AChR, acetylcholine receptors; ALS, amyotrophic lateral sclerosis; CMS, congenital myasthenic syndromes; dSTORM, direct stochastic optical reconstruction microscopy; ERCC1, excision repair crosscomplementing group 1; LEMS, Lambert-Eaton myasthenia syndrome; LRP4, low-density lipoprotein receptor-related protein 4; MuSK, muscle-specific kinase; MG, myasthenia gravis; MHC, myosin heavy chain isoform; mTOR, mammalian/mechanistic Target of Rapamycin; NMJ, neuromuscular junction; SOD1, superoxide dismutase 1; STED, stimulated emission depletion; SNAP25, synaptosomal associated protein-25; SNARE, soluble $\mathrm{N}$-ethylmaleimide-sensitive factor activating protein receptor; VGCC, voltage-gated calcium channels. 
double parallel rows of about 20 large particles in the p-face of the presynaptic membrane, which was interpreted as an active zone unit structure (Fukunaga et al., 1982). The macromolecules in the active zones interact with docked synaptic vesicles, which has been revealed in frog and mouse NMJs by electron microscopy tomography (Harlow et al., 2001; Nagwaney et al., 2009; Szule et al., 2012; Harlow et al., 2013; Jung et al., 2018). These docked synaptic vesicle fuse with the plasma membrane following calcium influx into the presynaptic terminals with the help of SNARE (Soluble $N$-ethylmaleimide-sensitive factor activating protein receptor) proteins including SNAP-25, synaptobrevin/VAMP, and syntaxin 1 (Jahn and Scheller, 2006; Sudhof and Rothman, 2009). The calcium influx required for neuromuscular transmission at adult mammalian NMJs is primarily mediated by P/Q-type voltagegated calcium channels (VGCC) (Uchitel et al., 1992; Rosato Siri and Uchitel, 1999). Electron microscopy studies have shown that presynaptic active zones are positioned apposed to the openings of post-synaptic junctional folds (Couteaux and PecotDechavassine, 1970; Patton et al., 2001). Junctional folds are small invaginations of the postsynaptic membrane that increases the area of acetylcholine receptors (AChRs) accumulation to efficiently receive $\mathrm{ACh}$ released from motor nerve terminals following depolarization by the action potential (Fertuck and Salpeter, 1974, 1976; Anderson and Cohen, 1977; Frank and Fischbach, 1979). Voltage-gated sodium channels are located in the troughs of post-synaptic junctional folds to generate action potentials (Caldwell, 2000). The activation of voltagegated sodium channels in mice is responsible for 15-20\% of the endplate potential (Hong and Chang, 1989). The high density of voltage-gated sodium channels and the increased local input resistance due to the narrow structure at the junctional folds are expected to amplify the neurotransmission for more efficient muscle depolarization (Wood and Slater, 2001). For the organization of postsynaptic specialization, agrin (a proteoglycan) is released from nerve terminals and binds to the low-density lipoprotein receptor (LDLR)-related protein 4 (LRP4) localized in the postsynaptic membrane (DeChiara et al., 1996; Kim et al., 2008). The interaction of agrin and LRP4 activates the protein tyrosine kinase function of the co-receptor muscle-specific kinase (MuSK), which localize together with AChR (Valenzuela et al., 1995). The activation of MuSK is essential for the clustering of AChRs through the AChR-associated protein Rapsyn (Apel et al., 1997; Lee et al., 2009) and the organizer protein Dok-7 (Beeson et al., 2006; Okada et al., 2006; Hallock et al., 2010).

Impairments of active zones are seen in pathological conditions, including the autoimmune disease, Lambert-Eaton myasthenia syndrome (LEMS), and Pierson's syndrome. LEMS is caused by autoantibodies including ones against P/Q-type VGCCs, and Pierson syndrome occurs due to mutation in lamb2 gene (Takamori et al., 2000; Zenker et al., 2004). Active zone loss may occur in these diseases due to a disruption in the interaction between muscle-derived laminin $\beta 2$ (Sanes and Hall, 1979; Hunter et al., 1989) and P/Q-type VGCC, which is necessary for the active zone organization (Figure 1) (Nishimune et al., 2004).
Although NMJs in most vertebrate species share many essential features, there are also significant differences (Figure 1), which will be described in this review. Human NMJs, are among the smallest and release the smallest number of ACh containing synaptic vesicles at the presynaptic terminal (Oda, 1984; Slater et al., 1992; Slater, 2015, 2017). However, they have very extensive postsynaptic junctional folds, which may amplify transmitter action (Wokke et al., 1990; Slater et al., 1992). Human NMJs are also susceptible to pathological processes and are targets in several neurodegenerative conditions, including aging. This review will focus on recent findings regarding human NMJs and a comparison of what is known about other mammalian NMJs. We will describe age-related changes at human NMJs and insights about potential mechanisms of aging obtained from animal models of accelerated aging. Furthermore, we will compare aging to other human neurological diseases that cause impairments of pre- and post-synaptic structures at NMJs.

\section{STRUCTURE OF THE HUMAN NEUROMUSCULAR JUNCTION}

Human NMJs analyzed by freeze-fracture electron microscopy show double parallel rows of large intramembranous particles on the cytosolic half of a plasma membrane (the P-face), containing 3-15 particles per row spaced $20 \mathrm{~nm}$ apart (Fukunaga et al., 1982). This structure is considered to represent an active zone unit. Similar structures are identified in rodent and lizard NMJs, which appear as double parallel rows of large intramembranous particles on the P-face (Ellisman et al., 1976; Walrond and Reese, 1985; Fukuoka et al., 1987). In humans, these active zone units are distributed at a density of 2.6 active zones per $\mu \mathrm{m}^{2}$ (Fukunaga et al., 1982). Similarly, active zone units in adult mouse NMJs appear in discrete locations within one presynaptic terminal of NMJs at a density of about 2.3-2.7 active zones per $\mu \mathrm{m}^{2}$ (Fukunaga et al., 1983; Fukuoka et al., 1987; Chen et al., 2012) (Table 1).

The application of super-resolution microscopy has revealed distribution patterns of synaptic proteins across different species at unprecedented details (Kittel et al., 2006; Willig et al., 2006; Dani et al., 2010; Ehmann et al., 2014; Nishimune et al., 2016; Jones et al., 2017). The molecular architecture of the human NMJ has been recently investigated using confocal and super-resolution microscopy (Jones et al., 2017). Confocal microscopy of motor nerve terminals at human NMJs showed distinctive "hotspots" of fluorescence of the synaptic vesicle protein SV2. This distribution pattern was qualitatively different from mouse nerve terminals, which showed homogeneity of SV2 labeling (Jones et al., 2017). Additionally, direct Stochastic Optical Reconstruction Microscopy (dSTORM) microscopy has been used to assess the nanoscale distribution of synaptosomal associated protein-25 (SNAP25), a SNARE protein in human NMJs. Parallel imaging of human and mouse NMJs using dSTORM revealed several differences between the two species. The intensity of SNAP25 labeling, the density of SNAP25 puncta within each bouton, the average area of SNAP25 puncta, and the area of SNAP25 puncta as a percentage of the total synaptic 


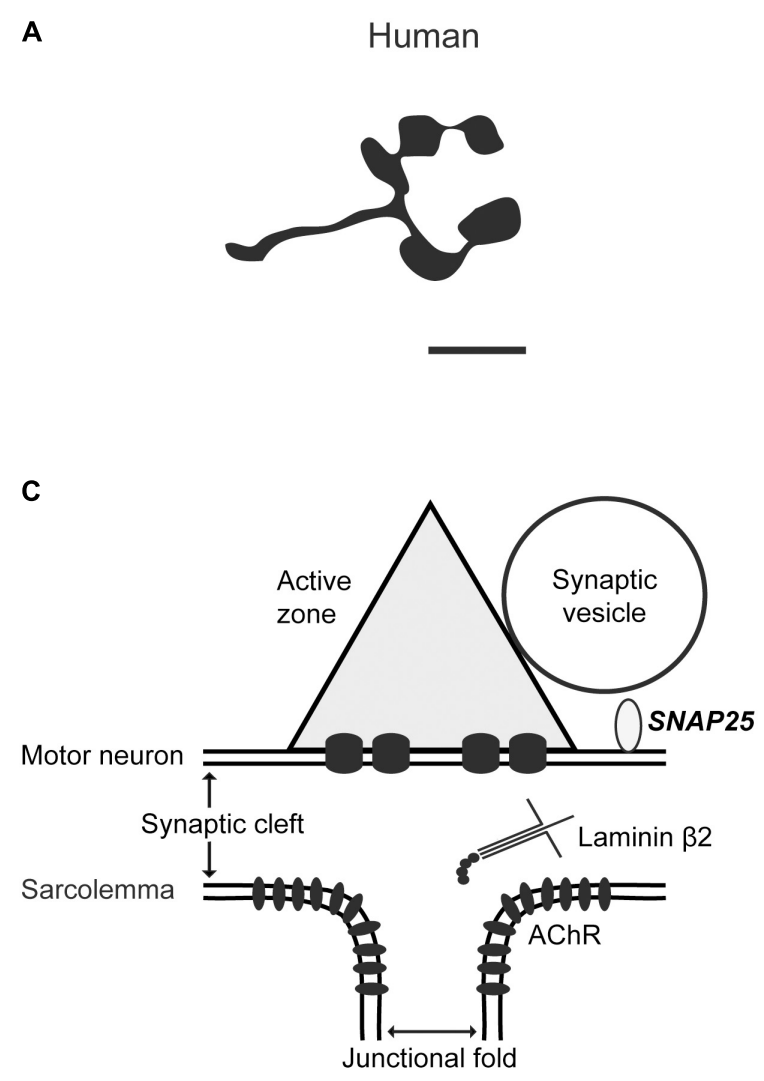

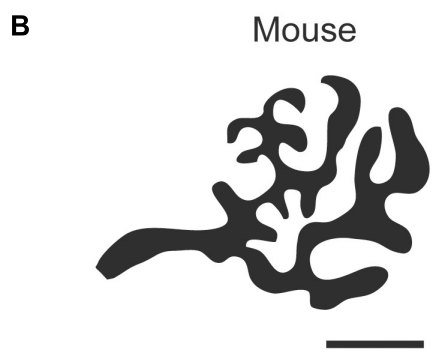

D

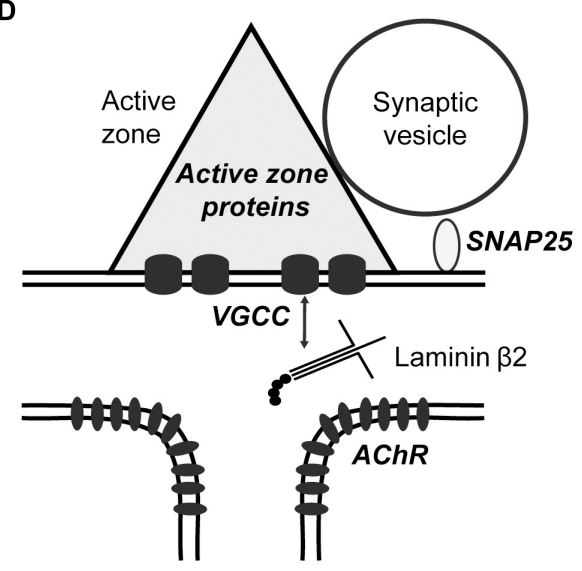

FIGURE 1 | Comparison between human and mouse neuromuscular junctions. Schematic diagrams show (A) human versus (B) mouse NMJs based on nerve-specific stains (adapted from Jones et al., 2017). The NMJ size and axon diameter are significantly smaller in humans compared to mice. Scale bar, $10 \mu \mathrm{m}$. A diagram depicting an active zone at the (C) human and (D) mouse NMJs. In mice, muscle-derived synapse organizer laminin $\beta 2$ interacts with presynaptic voltage-gated calcium channels (VGCC) to organize active zones (Nishimune et al., 2004). Super-resolution microscopy revealed the nanoscale localization of the SNARE protein synaptosomal associated protein-25 (SNAP25) in human and mouse NMJs (Jones et al., 2017), active zone-specific proteins, and acetylcholine receptors (AChR) in mice (Nishimune et al., 2016; York and Zheng, 2017), which are described in bold italic characters. The nanoscale localization of active zone-specific proteins and acetylcholine receptors in human NMJs has not been revealed yet.

bouton area were all significantly greater in human NMJs compared to mouse NMJs (Jones et al., 2017). The total area of SNAP25 labeling per NMJ is similar in both humans and mice at approximately $15 \mu \mathrm{m}^{2}$ per NMJ (Table $\mathbf{1}$ ).

Interestingly, this SNAP25 puncta density (approximately 15 puncta per $\mu \mathrm{m}^{2}$ ) is very similar to the density of other active zone proteins Bassoon, Piccolo and P/Q-type VGCC (approximately 10 puncta per $\mu \mathrm{m}^{2}$ ) as revealed in mouse NMJs by Stimulated Emission Depletion (STED) super-resolution microscopy (Nishimune et al., 2016). Jones et al. (2017) reported that they were unable to label human NMJs with antibodies against Bassoon or Piccolo, suggesting possible species-specific differences in these antigens (Jones et al., 2017). Although the distribution pattern of these active zonespecific proteins is unknown in human NMJs (Figure 1), analysis of mouse NMJs revealed punctate and overlapping patterns of active zone proteins Bassoon and P/Q-type VGCCs (Nishimune et al., 2016). Interestingly, active zone protein Piccolo does not co-localize with Bassoon. Instead, Piccolo puncta sandwiched a Bassoon punctum in a side-by-side pattern (Nishimune et al., 2016). Current progress in the understanding of active zone nanoarchitecture and mechanisms underlying active zone organization in mammalian NMJs has been reviewed previously (Badawi and Nishimune, 2018). Future studies using super-resolution microscopy will reveal a more detailed subcellular localization of active zone proteins and address species-specific differences that may exist.

The NMJ size relative to muscle fiber diameter is smaller in humans compared to lower vertebrates (frogs and mice), as revealed by electron microscopy (Slater et al., 1992) (Table 1). Confocal microscopy also revealed that human NMJs have a unique morphology, being significantly smaller and more fragmented compared to mice and rats. The axon diameter is 3.69 fold smaller, and the average area of AChR clusters is 3.33 fold smaller in humans compared to mice (Jones et al., 2017). The average number of AChRs in human vastus lateralis muscle is $2.6 \times 10^{7}$, as determined by bungarotoxin binding sites (Slater et al., 1992). In mice, the average number of AChRs is $8.7 \times 10^{7}$ in the sternomastoid muscle and $3.1 \times 10^{7}$ in the diaphragm, also determined by bungarotoxin binding sites (Albuquerque et al., 1974). In general, AChRs in mice cluster at a concentration of approximately 10,000 per $\mu \mathrm{m}^{2}$ in the 
TABLE 1 | Comparison between human and mouse NMJs.

\begin{tabular}{|c|c|c|}
\hline & Human & Mouse \\
\hline \multicolumn{3}{|l|}{ Pre-synaptic } \\
\hline Active zone size & $\begin{array}{l}153 \times 96 \mathrm{~nm} \\
\text { (Fukunaga et al., 1982) }\end{array}$ & $\begin{array}{l}80 \times 73 \mathrm{~nm} \\
\text { (Fukuoka et al., 1987) }\end{array}$ \\
\hline $\begin{array}{l}\text { Active zone } \\
\text { density }\end{array}$ & $\begin{array}{l}2.6 \text { per } \mu \mathrm{m}^{2} \\
\text { (Fukunaga et al., 1982) }\end{array}$ & $\begin{array}{l}\text { 2.3-2.7 per } \mu \mathrm{m}^{2} \\
\text { (Fukunaga et al., 1983; } \\
\text { Fukuoka et al., 1987; } \\
\text { Chen et al., 2012) }\end{array}$ \\
\hline $\begin{array}{l}\text { Bassoon and PQ-VGCC } \\
\text { puncta density per NMJ }\end{array}$ & Not reported & $\begin{array}{l}\text { 5-6 puncta per } \mu^{2}{ }^{2} \\
\text { (Nishimune et al., 2016) }\end{array}$ \\
\hline $\begin{array}{l}\text { SNAP25 puncta density } \\
\text { per NMJ }\end{array}$ & $\begin{array}{l}\sim 15 \text { puncta per } \mu \mathrm{m}^{2} \\
\text { (Jones et al., 2017) }\end{array}$ & $\begin{array}{l}\sim 15 \text { puncta per } \mu \mathrm{m}^{2} \\
\text { (Jones et al., 2017) }\end{array}$ \\
\hline Quantal content & 20-30 (Slater, 2017) & 50-100 (Slater, 2017) \\
\hline $\begin{array}{l}\text { Nerve terminal } \\
\text { area }\end{array}$ & $\begin{array}{l}122.7 \mu \mathrm{m}^{2} \\
\text { (Boehm et al., 2020) }\end{array}$ & $\begin{array}{l}304.0 \mu \mathrm{m}^{2} \\
\text { (Boehm et al., 2020) }\end{array}$ \\
\hline \multicolumn{3}{|l|}{ Post-synaptic } \\
\hline Endplate area & $\begin{array}{l}351.5 \mu \mathrm{m}^{2} \\
\text { (Boehm et al., 2020) }\end{array}$ & $\begin{array}{l}678.2 \mu \mathrm{m}^{2} \\
\text { (Boehm et al., 2020) }\end{array}$ \\
\hline $\begin{array}{l}\text { AChR number } \\
\text { per NMJ }\end{array}$ & $\begin{array}{l}\text { 1.3-3.4 × } 10^{7} \text { (Pestronk et al., } \\
\text { 1985; Slater et al., 1992) }\end{array}$ & $\begin{array}{l}3.1-8.7 \times 10^{7} \\
\text { (Albuquerque et al., 1974) }\end{array}$ \\
\hline Area of AChR clusters & $\begin{array}{l}71.7 \mu \mathrm{m}^{2} \\
\text { (Boehm et al., 2020) }\end{array}$ & $\begin{array}{l}238.5 \mu \mathrm{m}^{2} \\
\text { (Boehm et al., 2020) }\end{array}$ \\
\hline
\end{tabular}

postsynaptic membrane (Fertuck and Salpeter, 1976; Salpeter and Loring, 1985). The degree of overlap between the presynaptic motor nerve terminal and the post-synaptic component is similar between humans and mice (Slater et al., 1992; Jones et al., 2017). Although human NMJs are smaller than mouse NMJs, human motor nerves innervate muscle fibers up to twice the diameter of those in mice. The smaller size of human NMJs is not due to increased body size and mass because the NMJ size of mice and rats is similar, although rats are approximately 10 -fold larger than mice (Jones et al., 2017). Furthermore, human NMJs have extensive folding of post-synaptic junctional folds, which increases the local area of membrane about eight-fold while the increase is about six-fold for mouse NMJs (Slater et al., 1992; Slater, 2017), possibly resulting in post-synaptic amplification of neurotransmitter action through the presence of voltage-gated sodium channels in high density and the increased local input resistance (Slater, 2017). On the postsynaptic side of the mouse NMJ, dSTORM revealed the nanoscale distribution of AChRs (York and Zheng, 2017). AChRs are concentrated at the mouth of postsynaptic junctional folds directly apposed to active zones of presynaptic terminals. The accumulation of AChRs under presynaptic neurotransmitter release sites may allow effective synaptic transmission (York and Zheng, 2017). The AChRs of human NMJs have only been investigated at confocal-level resolution and has not yet been analyzed using super-resolution microscopy (Jones et al., 2017).

\section{AGE-RELATED CHANGES IN THE NEUROMUSCULAR JUNCTION}

The elderly, those over 65 years, suffer from a progressive loss of muscle mass (sarcopenia), strength, and function (for review see Roubenoff, 2000; Manini et al., 2013; Gonzalez-Freire et al., 2014;
Willadt et al., 2018; Clark, 2019). These losses contribute to decreased mobility, increased frailty, and risk for mortality (Fried et al., 2001). Aging in humans results in a one to $1.5 \%$ loss of strength per year after the 6th decade of life (Frontera et al., 2000). In humans, approximately $10-20 \%$ of skeletal muscle mass is lost by the 7 th decade of life compared to young adults (between 8 and 45 years) (Janssen et al., 2000; Vandervoort, 2002; Mitchell et al., 2012). This loss in muscle mass is likely due to motor unit loss (Lexell et al., 1988; Lexell, 1995) and subsequent atrophy of muscle fibers (Lexell et al., 1988). The loss of muscle fibers by apoptosis seems to be at an equal level between fast (Type II) and slow (Type I) muscle fiber types in humans (Lexell et al., 1983). However, there is preferential atrophy of fast fiber type compared with slow fiber type (Lexell et al., 1988; Klein et al., 2003). In mice, one study looking at muscle fiber type susceptibility in 29-month old mice demonstrated that denervation was greater in the fast extensor digitorum longus (EDL) muscle compared to the slow soleus muscle (Chai et al., 2011). However, another study using 24month old mice showed no differences in denervation between muscle fiber types (Valdez et al., 2012). Human autopsy studies have shown that aging is associated with a gradual loss of lumbar and cervical motor neurons (Kawamura et al., 1977; Tomlinson and Irving, 1977; Mittal and Logmani, 1987; Zhang et al., 1996). Mechanisms that lead to neuronal loss with aging in humans may involve impaired trophic signaling from the nervous system, local degeneration, increased oxidative stress in motor neurons, and feedback from dysfunctional muscle (Gonzalez-Freire et al., 2014).

Early studies have demonstrated age-related changes of NMJ innervation and AChR distribution using silver and cholinesterase staining in longitudinal sections of intercostal muscles obtained from human cadavers (between 32 and 76 years old) (Oda, 1984). Another study on autopsied subjects showed a significant decrease in presynaptic membrane length and a significant increase of postsynaptic membrane length of NMJs with aging (Arizono et al., 1984). Electron microscopy showed pre- and postsynaptic changes at the ultrastructural level (Wokke et al., 1990). Aging was associated with irregularly shaped presynaptic nerve terminals and the presence of junctional folds without an opposing nerve terminal in longitudinal sections of external intercostal muscles. Postsynaptically, electron microscopy revealed increased length and branching of the postsynaptic membrane, enlarged postsynaptic area, and degeneration of junctional folds (Wokke et al., 1990). Transverse-sections prepared from autopsied or biopsied vastus lateralis muscle provided strong evidence for repeated cycles of denervation-reinnervation, in which motor unit remodeling and fiber type grouping occurred (Lindboe and Torvik, 1982; Lexell and Downham, 1991; Mosole et al., 2014; Zampieri et al., 2016). Histological analysis of aged human muscles also showed a significant accumulation of severely atrophic, smaller sized, and angulated fibers, which suggested reinnervation failure in advanced age (Mosole et al., 2014). In aged rodent muscles, rearrangement, clustering, and angulation of muscle fibers in a motor unit have also been observed (Larsson, 1995; Rowan et al., 2011). 
In contrast to previous studies, a study by Jones and colleagues reported confocal micrographs of human NMJs in skeletal muscle obtained from amputation surgery and suggested conservation of synaptic structure across the lifespan (4th to 10th decades of life) (Jones et al., 2017). They observed a mild increase in axon diameter with increasing age. However, there were no age-associated changes in the innervation or fragmentation of NMJs in longitudinal sections of leg muscles, contradicting the earlier studies demonstrating age-related changes of NMJ innervation. They also report no significant change in the endplate area or muscle fiber diameter with age in the peroneus longus muscle (Jones et al., 2017). This finding is consistent with light microscopy analysis of human external intercostal muscles in which endplate size remained stable among ages (between 4 and 77 years old), and there was no sprouting of terminal axons (Wokke et al., 1990). A study by Gambino et al. (1990) in human posterior cricoarytenoid muscles (between 4 and 95 years old) demonstrated that there is no significant increase in NMJ length and the number of axonal terminal branches during adult life. It has also been reported that measures of presynaptic and postsynaptic structural relationships were maintained in the soleus muscle of the 24-month old rats despite aging-related changes (Deschenes et al., 2013). Differences between the human studies may be attributed to methodological disparities, which include (1) amputated versus post-mortem autopsied material, (2) light microscopy versus electron microscopy, (3) longitudinalsections versus transverse-sections, and (4) different muscle types with potentially different susceptibility. Table 2 summarizes the age-dependent changes of human NMJs and how they compare to rodent NMJs.

Studies in mice have shown that aging leads to AChR cluster fragmentation and progressive denervation of NMJs (Andonian and Fahim, 1988; Valdez et al., 2010; Li et al., 2011; Willadt et al., 2016, 2018). NMJ denervation precedes the degradation of spinal motor neurons, suggesting a "dying back" neuropathy or distal axonopathy during the aging of mice (Valdez et al., 2010; Chai et al., 2011). We have observed that aging in mice results in a reduced number and protein levels of presynaptic active zones in innervated NMJs (Chen et al., 2012; Nishimune et al., 2016). More specifically, there is selective degeneration of active zone proteins, P/Q-type VGCC and Bassoon, at aged NMJs of 29-month-old mice compared to that of 8-month-old mice (Nishimune et al., 2016). However, Piccolo protein level at these aged NMJs remained similar to that of adult NMJs, suggesting that NMJ active zone proteins decrease selectively prior to NMJ denervation during aging in mice. Our electrophysiology study showed that the lack of Bassoon impairs P/Q-type VGCC function (Nishimune et al., 2012). Thus, the loss of active zone proteins in aged NMJs reduces synaptic vesicle release sites and calcium influx, which may lead to denervation and a loss of muscle strength. The effect of aging on presynaptic active zone proteins in humans is unknown.

Age-related functional changes of human NMJs have been analyzed using electromyography (EMG) to evaluate compound muscle action potential (CMAP) and motor unit number estimation (MUNE). Additionally, single-fiber EMG (SFEMG)
TABLE 2 | Age-dependent changes in human and rodent NMJs.

\begin{tabular}{|c|c|c|}
\hline & Human & Rodent \\
\hline \multicolumn{3}{|c|}{ Presynaptic changes } \\
\hline $\begin{array}{l}\text { Active zone } \\
\text { density }\end{array}$ & Unknown & Decreases (Chen et al., 2012) \\
\hline $\begin{array}{l}\text { Active } \\
\text { zone-specific } \\
\text { proteins }\end{array}$ & Unknown & $\begin{array}{l}\text { Selective degeneration of } \\
\text { bassoon, piccolo and P/Q type } \\
\text { VGCC protein level and density } \\
\text { per synapse (Chen et al., 2012; } \\
\text { Nishimune et al., 2012; } \\
\text { Nishimune et al., 2016) }\end{array}$ \\
\hline $\begin{array}{l}\text { Synaptic } \\
\text { vesicle density }\end{array}$ & Unknown & $\begin{array}{l}\text { Decreases (Fahim and Robbins, } \\
\text { 1982; Banker et al., 1983) }\end{array}$ \\
\hline $\begin{array}{l}\text { Nerve terminal } \\
\text { branching }\end{array}$ & $\begin{array}{l}\text { Increases (Oda, 1984), no } \\
\text { change (Gambino et al., 1990) }\end{array}$ & $\begin{array}{l}\text { Increases (Fahim et al., 1983; Li } \\
\text { et al., 2011; Valdez et al., 2012) }\end{array}$ \\
\hline Denervation & $\begin{array}{l}\text { Increases in intercoastal (Oda, } \\
\text { 1984) and VL muscles (Lexell } \\
\text { and Downham, 1991; Mosole } \\
\text { et al., 2014; Zampieri et al., } \\
\text { 2016), no change in the } \\
\text { peroneus longus muscle } \\
\text { (Jones et al., 2017) }\end{array}$ & $\begin{array}{l}\text { Increases in TA, plantaris, and } \\
\text { EDL muscle (Fahim and } \\
\text { Robbins, 1982; Deschenes } \\
\text { et al., 2010; Valdez et al., 2010; } \\
\text { Chai et al., 2011) }\end{array}$ \\
\hline \multicolumn{3}{|c|}{ Postsynaptic changes } \\
\hline $\begin{array}{l}\mathrm{NMJ} \\
\text { fragmentation }\end{array}$ & $\begin{array}{l}\text { No change in the peroneus } \\
\text { longus muscle } \\
\text { (Jones et al., 2017) }\end{array}$ & $\begin{array}{l}\text { Increases in the EDL, } \\
\text { diaphragm, soleus, } \\
\text { sternomastoid, and TA muscles } \\
\text { (Andonian and Fahim, 1988; } \\
\text { Valdez et al., 2010; Li et al., } \\
\text { 2011; Willadt et al., 2016) }\end{array}$ \\
\hline Endplate area & $\begin{array}{l}\text { Increases (Oda, 1984) and no } \\
\text { change (Wokke et al., 1990) in } \\
\text { intercostal muscles. No change } \\
\text { in the peroneus longus muscle } \\
\text { (Jones et al., 2017) }\end{array}$ & $\begin{array}{l}\text { No change in the EDC, EDL, } \\
\text { GM, and soleus muscles } \\
\text { (Banker et al., 1983) }\end{array}$ \\
\hline $\begin{array}{l}\text { Postsynaptic } \\
\text { folds number } \\
\text { and regularity }\end{array}$ & $\begin{array}{l}\text { Decreases (Arizono et al., } \\
\text { 1984; Wokke et al., 1990) }\end{array}$ & $\begin{array}{l}\text { Decreases (Fahim and } \\
\text { Robbins, 1982) }\end{array}$ \\
\hline
\end{tabular}

The age range for human studies is 4-95 years, and the age range for rodent studies is 21 days to 33 months (mice) and 56 days to 24 months (rats). EDC, extensor digitorum communis; EDL, extensor digitorum longus; GM, gluteus maximus; NMJ, neuromuscular junction; TA, tibialis anterior; VGCC, voltage-gated calcium channel; VL, vastus lateralis.

has been used to analyze action potentials from individual muscle fibers and the variation in time of two action potentials of the same motor unit (jitter). The MUNE values of limb muscles decrease in older humans compared to that of the young (Galea, 1996; McNeil et al., 2005; Power et al., 2010; Hourigan et al., 2015; Piasecki et al., 2016). This decrease in MUNE values is consistent with the gradual loss of motor neurons (Kawamura et al., 1977; Tomlinson and Irving, 1977; Mittal and Logmani, 1987). In addition, MUNE values decrease in the skeletal muscles of aged mice (Sheth et al., 2018; Chugh et al., 2020). In accordance with the decrease of MUNE values and motor neuron number, the CMAP decreases in old humans compared to that of the young (Piasecki et al., 2016), and in aged mice compared to young mice (Sheth et al., 2018). SFEMG studies have found mild increases in jitter in some muscles suggesting a mild change in neurotransmission efficiency in humans between 10 and 90 years old (Bromberg and Scott, 1994). 
Age-related functional changes of rodent NMJs have been studied using dissected nerve-muscle preparations, direct stimulation of motor nerves, and intracellular recordings from the muscle, which has not been done for human studies (Willadt et al., 2018). Aged mice show decreased MUNE values, as mentioned previously (Sheth et al., 2018; Chugh et al., 2020), and age-related increase of the blockade of synaptic transmission (Chugh et al., 2020). These findings seem consistent with the NMJ denervation observed in old mice. However, many studies of aged mice and rats revealed increases or no change of miniature endplate potential (mEPP) amplitude, endplate potential, and quantal content (Banker et al., 1983; Kelly and Robbins, 1983; Smith, 1988; Fahim, 1997; Willadt et al., 2016). Some of these changes may relate to the reduced $\mathrm{Ca}^{2+}$ clearance rates in presynaptic terminals (Smith, 1988) or increased input resistance postsynaptic membrane in some aged NMJs (Banker et al., 1983; Fahim, 1997). These age-related changes may be compensatory mechanisms for the reduced MUNE; however, they do not seem to be in accordance with the age-related increase of the blockade of synaptic transmission (Chugh et al., 2020) or the NMJ denervation observed in old mice. Furthermore, the increase of NMJ fragmentation observed in aged mice was not associated with functional impairment (Willadt et al., 2016).

Taken together, these results suggest that age-dependent changes in structure and motor unit number (denervation) occur in human NMJs, but further studies are needed to reveal the relationship between functional and structural changes related to the aging of NMJs. The sections below will discuss mouse models that reproduce key phenotypes of neuromuscular and cellular impairment seen during aging. We will also discuss potential similarities in molecular pathways between aging and neuromuscular disease because the phenotypes of human aging, and that of neuromuscular disease model mice share defects in pre- and postsynaptic NMJ structures.

\section{INSIGHTS FROM ANIMAL MODELS OF ACCELERATED AGING}

Human progeroid syndromes are genetic disorders characterized by a shortened lifespan and the premature development of phenotypes, which are normally associated with advanced age (Martin, 1978). Progeroid syndromes can occur as a result of a single gene mutation (Martin, 1978; Warner and Sierra, 2003). Therefore, mouse models of progeroid syndromes have been developed to study the mechanisms and pathways involved in aging. Mouse models of accelerated aging are useful because of their short lifespan, the specific targeting of a single gene, and the phenotypic similarities with physiological aging (Harkema et al., 2016). Obtaining insights into the aging process can lead to the identification of possible targets for sarcopenia prevention. In the section below, we will discuss observations made in few mouse models of accelerated aging and compare them to neuromuscular aging phenotypes described in aged mice and elderly humans. The following mouse models were selected based on the association between the gene modifications and neuromuscular dysfunction phenotypes. The selection is not ment to cover all animal models of accelerated aging. Many reviews provide a more extensive list of progeroid mouse models associated with gene modifications resulting in additional pathologic phenotypes implicated in physiological aging, for example in the central nervous system, cardiovascular system, bones, and joints (Carrero et al., 2016; Harkema et al., 2016; Folgueras et al., 2018).

\section{Zmpste24-/- Mice}

Accelerated aging was observed in a mouse model with a deletion of zinc metalloproteinase (Zmpste24) required for processing of prelamin A to lamin A (Leung et al., 2001; Bergo et al., 2002). Lamin A is a component of the nuclear envelope and interacts with membrane-associated proteins to form the nuclear lamina (Aebi et al., 1986). Lamin A has been suggested to play a role in physiological aging (Scaffidi and Misteli, 2006) because a gene mutation in Lamin A (Lmna) causes incomplete processing of prelamin A protein and the affected children show symptoms of premature aging (De Sandre-Giovannoli et al., 2003; Eriksson et al., 2003). The Zmpste24-/- model has a defect in prelamin A processing and is similar to the Hutchinson-Gilford progeria syndrome (Bergo et al., 2002). Muscles of Zmpste24-/mice exhibit characteristics of sarcopenia, including both muscle atrophy and weakness (Bergo et al., 2002; Greising et al., 2012). More specifically, the contractile capacity of muscles of the anterior leg (extensor hallucis longus, EDL and tibialis anterior) were $30-90 \%$ weaker than those of control mice (Greising et al., 2012). Consistently, hindlimb muscles (EDL, tibialis anterior, soleus, and gastrocnemius) were $32-47 \%$ smaller in the Zmpste $24^{-/-}$mice and contained significantly more collagen compared to control littermates (Greising et al., 2012). Additionally, the ankle range of motion was $70 \%$ lower in Zmpste $24^{-/-}$than control mice. Combined together, muscle atrophy, collagen accumulation, and abnormal joint mechanics contribute to poor neuromuscular performance and muscle weakness shown by Zmpste24-/- mice (Greising et al., 2012). These phenotypes caused by decreased Zmpste24 activity are similar to those seen in aged mice and elderly humans, suggesting that defective lamin A processing plays a role in the aging process. These observations are consistent with the recent demonstration of age-related decline in the expression of lamin $\mathrm{A} / \mathrm{C}$ in the synaptic region of muscles and a role of lamin $\mathrm{A} / \mathrm{C}$ in preventing NMJ degeneration (Gao et al., 2020).

\section{$B u b 1 b^{\mathrm{H} / \mathrm{H}}$ and Bub1b+/GTTA Mice}

Accelerated sarcopenia and a shortened lifespan were observed in mice with low levels of the spindle assembly checkpoint protein BubR1, including $B u b 1 b^{\mathrm{H} / \mathrm{H}}$ mice with two hypomorphic alleles and $B u b 1 b^{+/ \text {GTTA }}$ mice with the human nonsense mutation 2211insGTTA (Baker et al., 2004; Wijshake et al., 2012). These mice show a decrease in muscle fiber diameter in gastrocnemius, paraspinal, and abdominal muscles, with increased intermuscular fibrosis, and impaired regenerative capacity (Baker et al., 2008; Wijshake et al., 2012). The effect of BubR1 deficiency on NMJ structure and the innervation rate remain unknown. However, BubR1 deficiency in $B u b 1 b^{\mathrm{H} / \mathrm{H}}$ mice is a trigger for $C d k n 2 a$ 
locus activation, which encodes the tumor suppressors $\mathrm{p} 16^{\text {Ink4a }}$ and p19ARF (Baker et al., 2008). Both p16 ${ }^{\text {Ink4a }}$ and p19 ${ }^{\mathrm{ARF}}$ are effectors of cellular senescence (Baker et al., 2008) or a state of irreversible growth arrest (Collado et al., 2007). The levels of the senescence markers, $\mathrm{p} 16^{\mathrm{Ink} 4 \mathrm{a}}$ and $\mathrm{p} 19^{\mathrm{ARF}}$, were also found to be elevated in the skeletal muscle of $B u b 1 b^{+/ G T T A}$ mice (Wijshake et al., 2012). The inducible clearance of $\mathrm{p}^{16} 6^{\text {Ink4a }}$ positive senescent cells upon administration of a drug in $B u b 1 b^{\mathrm{H} / \mathrm{H}}$ mice results in attenuation of sarcopenia and premature aging (Baker et al., 2011). Furthermore, breeding $B u b 1 b^{\mathrm{H} / \mathrm{H}}$ mutant mice on a p16 ${ }^{\text {Ink4a }}$ homozygous-null background attenuated cellular senescence and premature aging in skeletal tissues, and a $25 \%$ extension in lifespan compared to $B u b 1 b^{\mathrm{H} / \mathrm{H}}$ mice (Baker et al., 2008). These results, combined with the decline of BubR1 expression in aged wild-type mice (Baker et al., 2004), suggest that BubR1 may play a role in physiological aging.

\section{$\operatorname{Ercc1}^{\Delta /-}$ Mice}

Genotoxic stress as a result of cumulative damage to DNA is considered a dominant mechanism underlying aging (Hoeijmakers, 2009). The excision repair cross-complementing group 1 (ERCC1) gene functions in the nucleotide excision repair pathway (Westerveld et al., 1984). Previous studies of ERCC1 deficient patients (Jaspers et al., 2007; Ahmad et al., 2010) and ERCC1 $1^{-/-}$mice (Weeda et al., 1997) have indicated that a loss of ERCC1 nuclease function causes a premature aging degenerative phenotype in several organ systems and juvenile death. The very short lifespan of $E R C C 1^{-/-}$mice (which is less than 38 days) hinders the investigation of age-dependent neurodegeneration. Therefore, Weeda et al. (1997) also examined ERCC1 $1^{\Delta /-}$ mice lacking one allele and having reduced activity in the other allele due to a seven amino-acid carboxy-terminal truncation. $E R C C 1^{\Delta /-}$ mice have a shortened life span of 6-7 months, severe locomotor deficits, and reduced ability to maintain balance (de Waard et al., 2010). Grip strength and accelerating rotarod test performances are reduced in $E R C C 1^{\Delta /-}$ mice at 16 weeks of age. Full and partial denervation of NMJs occurs in the lumbrical muscles of $E R C C 1^{\Delta /-}$ mice at 8 and 16 weeks. There is also a significant increase in the number of motor endplates that are innervated by more than one incoming axon collateral in ERCC $C^{\Delta /-}$ mice (de Waard et al., 2010). This sprouting of new collateral axonal branches occurs as a compensatory mechanism to reinnervate denervated muscle fibers. These results suggest that the accumulation of DNA damage may play a role in neuronal aging and motor neuron vulnerability in aging.

\section{Sod1-/- Mice}

Oxidative stress is one of the leading theories on mechanisms underlying age-related muscle denervation (Fulle et al., 2004; Salmon et al., 2010). Reactive oxygen species-mediated oxidative damage to proteins, lipids, and DNA are kept in check by antioxidants under normal physiological conditions. However, excessive reactive oxygen species production can overwhelm the antioxidant defense, leading to increased oxidative damage of cellular machinery (Park, 2015). Studies on the genetic ablation of superoxide dismutase 1 (SOD1), a free radical scavenging enzyme, have shown that superoxide $\left(\mathrm{O}_{2}{ }^{-} / \mathrm{HO}_{2}\right)$ can be toxic, and the lack of $\mathrm{Cu} / \mathrm{Zn}$ SOD contributes to a deleterious phenotype in various model systems (Phillips et al., 1989; Ho et al., 1998; McFadden et al., 1999; Sanchez et al., 2005; Muller et al., 2006). Mice lacking Cu/Zn SOD1 (Sod1 ${ }^{-/-}$) show phenotypes that resemble an acceleration of normal age-related sarcopenia (Muller et al., 2006) and exhibit a 30\% reduction in lifespan (Elchuri et al., 2005). Hindlimb muscle mass in Sod $1^{-/-}$mice is approximately $50 \%$ lower than in age-matched wild-type mice. Skeletal muscle tissue from Sod1 $1^{-/-}$mice show increased oxidative damage of proteins, lipids, and DNA compared to control mice. These differences are accompanied by a $40 \%$ decrease in voluntary wheel running at 6 months of age, and about $50 \%$ worse Rotarod performance in Sod $1^{-/-}$ mice compared to wildtype littermates (Muller et al., 2006). Interestingly, depletion of $\mathrm{Cu} / \mathrm{Zn} \mathrm{SOD} 1$ in either the motor neuron or muscle alone is not sufficient to reproduce a sarcopenic phenotype and that a loss of $\mathrm{Cu} / \mathrm{Zn}$ SOD1 in both neurons and muscle is required to generate atrophy (Zhang et al., 2013; Sataranatarajan et al., 2015). Furthermore, Sod $1^{-/-}$mice display progressive NMJ denervation despite the absence of losses of spinal cord motor neurons and ventral root axons (Flood et al., 1999; Shefner et al., 1999; Jang et al., 2010; Fischer et al., 2011, 2012). Denervation and sprouting occur in these mice at 14 months of age, preceding muscle fiber loss that occurs between 3 and 4 months of age (Muller et al., 2006; Fischer et al., 2011, 2012). Muscle denervation and abnormalities in motor axon morphology of Sod1 $1^{-/-}$mice are greater in the gastrocnemius and tibialis anterior muscles compared to the soleus muscle (Muller et al., 2006; Fischer et al., 2011, 2012). The gastrocnemius and tibialis anterior muscles have a higher proportion of fast muscle fibers, and the soleus muscle has a higher proportion of slow muscle fibers. Therefore, fast muscles are more vulnerable to NMJ denervation and muscle fiber loss in Sod $1^{-/-}$mice, similar to what occurs in humans aging studies (Lexell et al., 1988; Lexell, 1995). Myosin heavy chain isoform (MHC) type II (fast) muscle fibers in elderly humans are more affected than $\mathrm{MHC}$ isoform type I (slow) fibers during age-related NMJ denervation (Lexell et al., 1988; Lexell, 1995). Overall, these results demonstrate that $\mathrm{Cu} / \mathrm{Zn} \mathrm{SOD} 1$ is necessary for normal neuromuscular functions and suppression of age-dependent neuromuscular degeneration.

These animal models show accelerated aging with defects of the neuromuscular system including sarcopenia, axonal sprouting, and denervation like physiological aging. These mice provides opportunities to study NMJ changes, understand pathological mechanisms, and identify therapeutic targets to delay or prevent the onset of age-related neuromuscular impairments.

\section{COMPARISON WITH OTHER DISEASES THAT AFFECT THE NMJ}

The mechanisms that form NMJs during development or degenerate NMJs in neuromuscular diseases may underlie the mechanisms of physiological aging in humans. For example, a loss in presynaptic active zones has been observed in NMJs of 
aged mice (Chen et al., 2012). Similarly, active zone structure is impaired in human neurological diseases, including LEMS and Pierson syndrome. LEMS patients develop autoantibodies against P/Q-type VGCCs, which is thought to cause internalization of P/Q-type VGCCs into nerve terminals (Lambert and Elmqvist, 1971; Fukunaga et al., 1982; Flink and Atchison, 2003). LEMS patients exhibit a reduced number of NMJ active zones, reduced synaptic transmission, weakened muscles, and fatigue (Lambert and Elmqvist, 1971; Fukunaga et al., 1982) similar to what is observed in aging. Interestingly, some LEMS patients develop autoantibodies specifically against the domain of P/Q-type VGCCs, where laminin $\beta 2$ binds to (Takamori et al., 2000; Nishimune et al., 2004). These autoantibodies may cause a loss of interaction between the synapse organizer laminin $\beta 2$ and VGCCs, which may inhibit the organization of active zones. Consistently, mice immunized with LEMS patient IgGs also show a reduced number of active zones (Fukunaga et al., 1983). Thus, the interaction between P/Q-type VGCCs and laminin $\beta 2$ is essential for organizing the presynaptic active zones. Meanwhile, Pierson syndrome patients lack functional laminin $\beta 2$ due to a genetic mutation and show a reduction in active zones at the NMJ, impairments in synaptic transmission including reduced mEPP frequency and amplitude, and denervation (Zenker et al., 2004; Maselli et al., 2009). These clinical characteristics of Pierson syndrome are consistent with the phenotypes of laminin $\beta 2$ knockout mice (Noakes et al., 1995). Together, these observations suggest that laminin $\beta 2$ plays an important role in active zone organization in humans and a potential role in the maintenance of active zones in aged NMJs.

Myasthenia gravis (MG), the most common disorder of NMJs, is caused by autoantibodies against postsynaptic membrane proteins (Conti-Fine et al., 2006; Vincent et al., 2006; Shigemoto et al., 2010). The characteristic clinical features of MG include fatigue, muscular atrophy, weakness, and ptosis (Slater et al., 2006; Phillips and Vincent, 2016). Analyses of patient sera showed that the majority of MG patients produce autoantibodies against AChRs ( 85\%). Autoantibodies against muscle-specific kinase (MuSK) makeup $\sim 8 \%$ of MG patients and were found in $70 \%$ of $\mathrm{MG}$ patients who lacked autoantibodies against AChRs (Gilhus and Verschuuren, 2015; Binks et al., 2016). Furthermore, autoantibodies against LRP4 were found in 2$54 \%$ of MG patients who were negative for anti-AChR and anti-MuSK antibodies (Higuchi et al., 2011; Zhang et al., 2012; Zisimopoulou et al., 2014). Various studies using animal models that received injections of MG patient IgG have shown that these antibodies are pathogenic. AChR antibodies increase the rate of $A C h R$ internalization, and a loss of AChRs at the NMJ impairs neuromuscular transmission (Engel et al., 1977; Phillips and Vincent, 2016). The postsynaptic membrane shows a diminished response to $\mathrm{ACh}$ and a reduction in EPPs and mEPPs amplitudes (Loutrari et al., 1992; Ruff and Lennon, 2008). MG patients' MuSK antibodies prevent the assembly and activation of the agrin-LRP4-MuSK complex necessary for NMJ maintenance (Huijbers et al., 2013; Otsuka et al., 2015). MuSK and LRP4-immunized mice also show impairments of neuromuscular transmission as well as a reduction in the size of motor terminals apposing AChR clusters at NMJs (Mori et al., 2012; Zhang et al., 2012; Mori et al., 2017). Transverse-sections of muscles from MuSK-immunized rabbits showed angular muscle fibers (Shigemoto et al., 2006) similar to what is seen in transverse-sections of aged muscle fibers (Larsson, 1995; Zampieri et al., 2016). LRP4-immunized mice showed significantly decreased staining areas of the presynaptic proteins, synaptophysin and bassoon, at NMJs compared to controls (Mori et al., 2017). However, the normalized bassoon staining area was unchanged compared to control mice because the synapse area is also reduced in these mice (Mori et al., 2017). It is worth noting that gene mutations in the agrin-LRP4MuSK-Dok7-rapsyn-AChR pathway, including the genes $A G R N$, MUSK, DOK7, RAPSN, cause congenital myasthenic syndromes (CMSs). CMSs are characterized by weakness and fatigue, similar to MG (Rothbart, 1937). However, CMS is not a degenerative disorder like aging but a developmental disorder, which has been reviewed previously (Engel et al., 2010, 2015; Webster, 2018). In aged mice, the agrin-LRP4-MuSK-AChR signaling pathway is implicated in aging-associated NMJ deficits (Zhao et al., 2018). LRP4 protein levels are decreased in aged muscles and restoring the levels of LRP4 by transgenic expression or stabilization with sarcoglycan alpha maintained NMJ innervation, alleviated AChR fragmentation, and improved synaptic transmission (Zhao et al., 2018). Furthermore, viral-mediated upregulation of DOK7 in aged mouse muscle significantly enhanced motor function, muscle strength, NMJ innervation, and compound muscle action potential amplitudes (Ueta et al., 2020). Thus, studying the role of the agrin-LRP4-MuSK-Dok7-rapsyn-AChR signaling pathway in aging has identified a potential therapeutic target for alleviating NMJ decline in aging. This elucidation was helped by the prior knowledge demonstrating the importance of this signaling pathway for NMJ development, maintenance, and degeneration in MG (Li et al., 2018).

Amyotrophic lateral sclerosis (ALS) is a neurodegenerative disorder characterized by a gradual loss of motor neurons that leads to paralysis and death (Brown, 1995). The first gene mutations associated with familial ALS were identified in the SOD1 gene (Rosen et al., 1993). These findings led to the development of the transgenic mouse model for ALS expressing the human SOD1 gene with glycine 93 to alanine (G93A) mutation identified in patients (SOD1 ${ }^{\mathrm{G} 93 \mathrm{~A}}$ mice) (Gurney et al., 1994). SOD $1^{\mathrm{G} 93 A}$ mice exhibit progressive denervation, motor neuron loss, muscle weakness, and paralysis similar to ALS patients (Gurney et al., 1994; Chiu et al., 1995; Tu et al., 1996; Wong and Martin, 2010; Rocha et al., 2013; Dobrowolny et al., 2018). NMJ denervation is observed as early as 47 days of age in these mice (Kennel et al., 1996; Fischer et al., 2004) and precedes both motor neuron loss (Gurney et al., 1994; Dadon-Nachum et al., 2011) and muscle atrophy (Brooks et al., 2004; Marcuzzo et al., 2011). These characteristics are similar to those observed in the rodent models of aging (Chai et al., 2011; Valdez et al., 2012) as well as in SOD1 $1^{-/-}$mouse models of accelerated aging (Shi et al., 2014). In addition, SOD ${ }^{\mathrm{G} 93 \mathrm{~A}}$ mice display preferential denervation of fast-twitch muscles (Atkin et al., 2005; Hegedus et al., 2007, 2008). It has been suggested that both fast type muscle and motor units are preferentially vulnerable to the disease process in ALS patients (Dengler et al., 1990; Sanjak et al., 2001). 
This increased susceptibility to NMJ denervation in fast type muscles has also been demonstrated in aged mice (Chai et al., 2011; Valdez et al., 2012) and SOD1 ${ }^{-/-}$mouse models of accelerated aging (Fischer et al., 2011, 2012).

Identifying similarities between aging and phenotypes of neurodegenerative diseases may suggest common molecular pathways that underlie aging-related degeneration of NMJs. Furthermore, understanding the molecular basis of NMJ dysfunction in animal models is essential for translating research to study aging in humans and search for candidate targets for therapeutic intervention of sarcopenia and frailty. For example, a mechanism of peripheral neuropathy elucidated from aged mice may provide a novel therapeutic approach for age-related degeneration observed in the elderly (Yuan et al., 2018). The previous reviews have discussed the possible functional significance associated with age-related changes in NMJ structure, which include denervation, fragmentation, axonal branching, decreased synaptic vesicles, and altered postsynaptic folding (Willadt et al., 2016; Li et al., 2018). Importantly, studying NMJ dysfunction is essential for understanding musculoskeletal impairment during aging.

\section{INTERVENTIONS TO IMPROVE AGE-RELATED NMJ DYSFUNCTION IN HUMANS}

Exercise and caloric restriction attenuate age-related declines in the mammalian neuromuscular system and are potential interventions to delay the onset of age-related NMJ dysfunction and sarcopenia (Cadore et al., 2014; Most et al., 2017; Lopez et al., 2018; Lavin et al., 2019). Aging leads to a loss of motor units, as described in the previous section titled "age-related changes in the NMJ." In humans, a study on master athletes indicates that high levels of life-long physical activity may ameliorate this loss of functional motor units in the tibialis anterior muscle into the 7th decade of life compared to agematched controls (Power et al., 2010). Unlike the tibialis anterior leg muscle, the estimated number of functional motor units in the biceps brachii arm muscle of masters runners was lower in old age compared with young adults (Power et al., 2012). These findings indicate that high levels of chronic activation is necessary for delaying the age-related loss of motor units, and the beneficial effect is specific to the muscle exposed to the long term high levels of physical activity (Power et al., 2012). The number of functional motor units in a human muscle group can be estimated using a minimally invasive electrophysiological technique (decomposition-enhanced spike-triggered averaging) (McComas et al., 1971). This technique can also provide indirect evidence of collateral reinnervation using the peak amplitude of the mean surface-detected motor unit potential (Power et al., 2016). World champion master runners in their ninth decade of life had a greater number of remaining motor units and reduced collateral reinnervation compared to age-matched non-athletes (Power et al., 2016). Furthermore, master athletes had a $14 \%$ greater amount of excitable muscle mass and better neuromuscular transmission stability or preterminal axon stability, as indicated by lower jitter values, compared with agematched non-athletes (Power et al., 2016). Additionally, biopsies from seniors physically active at high-level (65-79 years old) revealed a significantly higher percentage of slow-type myofibers and increased muscle fiber-type groupings, suggesting that longterm cycles of denervation/reinnervation have occurred (Mosole et al., 2014). People aged 70 years or older who reported walking 4-7 days per week showed a reduced risk of lowerbody mobility impairments compared to elderly who reported walking fewer days per week (Clark, 1996). Moderate to high levels of physical activity in aged adults was associated with a significant increase in life expectancy and disability-free years before death compared to aged adults who reported low physical activity (Ferrucci et al., 1999). Starting exercise training in old age can also lead to significant health improvements. Nine weeks of training improved muscle strength and recovered myofiber atrophy in 70-year-old subjects compared to pre-training (Zampieri et al., 2016). Together, these results demonstrate that exercise maintains neuromuscular stability and ameliorates the loss of motor units associated with aging well into the later decades of human life.

In rodents, endurance exercise has a beneficial effect on NMJs in the aging muscle. Running wheel and treadmill running has been shown to reduce post-synaptic AChR fragmentation related to rodent aging, and help maintain $\mathrm{NMJ}$ innervation and endplate area (Andonian and Fahim, 1988; Fahim, 1997; Valdez et al., 2010; Deschenes et al., 2011; Cheng et al., 2013). Presynaptically, exercise has been shown to maintain active zone protein content. Active zone protein levels in NMJs are reduced during aging, but resistance training ameliorated the loss of Bassoon at NMJs of 24-month-old aged rats to young adult levels (Nishimune et al., 2012). This finding is consistent with endurance training improving NMJ function in aged mice, which was revealed using electrophysiology (Fahim, 1997). To our knowledge, no other studies investigated active zone proteins at NMJs combined with exercise training. More work is needed to understand the molecular mechanisms by which exercise modulates active zones and active zone proteins during aging.

Caloric restriction is a long-term dietary intervention in which caloric intake is reduced, but malnutrition is avoided (Anderson and Weindruch, 2012). The first description of the possible benefits and mechanisms of caloric restriction in aging has been demonstrated through the studies of rodent and invertebrate species (Fontana et al., 2010; Anderson and Weindruch, 2012). The caloric restriction prolonged the lifespan of rodents in an inverse linear manner when caloric intake is reduced at $10-30 \%$ compared to ad libitum intake of a standard diet (Weindruch et al., 1986; Anderson and Weindruch, 2010). Furthermore, a $40 \%$ reduction in caloric intake in mice from 4 to 24 months of age led to the maintenance of NMJs in the tibialis anterior muscle compared to control mice fed a standard diet ad libitum (Valdez et al., 2010). The frequencies of AChR fragmentation and NMJ denervation were significantly lower in these calorically restricted mice than in control aged mice indicating an attenuation of the age-related changes in the NMJ structure (Valdez et al., 2010). The use of the caloric restriction mimetic, resveratrol had a beneficial effect on NMJs and preserving muscle 
fiber morphology in the EDL muscle of 2-year-old mice (Stockinger et al., 2017). The beneficial effect of caloric restriction on health has also been reported in non-human primates (Roth et al., 2000). In rhesus monkeys, caloric restriction of $30 \%$ reduced intake improves survival and delays the onset of sarcopenia and age-associated diseases (McKiernan et al., 2011). Analysis of vastus lateralis muscle biopsies showed that caloric restriction attenuated age-related changes in the proportion of Type II muscle fibers and fiber transversesectional area (McKiernan et al., 2011). Epidemiological studies show evidence that caloric restriction without malnutrition may also have health-promoting effects in humans. A large population of centenarians is found on the island of Okinawa, where individuals reportedly eat fewer calories on average than people in mainland Japan (Chan et al., 1997). Randomized controlled trials of caloric restriction in the United States show a decline in markers of oxidative stress and DNA-damage after 6 months compared to controls on a weight-maintenance diet (Heilbronn et al., 2006; Civitarese et al., 2007). Skeletal muscle biopsies collected from the trial participants showed that caloric restriction induces mitochondrial biogenesis and decreases superoxide dismutase activity, which in turn lowers oxidative stress (Civitarese et al., 2007). A caloric restriction trial in healthy, adult humans demonstrated that a $15 \%$ caloric restriction over 2-years resulted in beneficial metabolic adaption and a reduction in biomarkers associated with aging compared to an ad libitum control group (Redman et al., 2018). Studies in Caenorhabditis elegans, Drosophila, and yeast suggest a possible link between the TOR (Target of Rapamycin) pathway and caloric restriction (Kapahi et al., 2004; Kaeberlein et al., 2005; Hansen et al., 2007). The potential role of mTOR signaling in the aging process of these model organisms in addition to mammals has been reviewed previously (Saxton and Sabatini, 2017; Papadopoli et al., 2019). In mice, a sirtuin, Sirt1 has been shown to regulate aging and longevity. Brain specific overexpression of Sirt1 in mice protected against the agerelated decline in skeletal muscle and resulted in more youthfulappearing NMJs (Ghosh and Zhou, 2015; Snyder-Warwick et al., 2018). The mechanisms linking Sirt1 from the hypothalamus to skeletal muscle in mice and the involvement of SIRT1 in humans remains to be elucidated. Aside from caloric restriction,

\section{REFERENCES}

Aebi, U., Cohn, J., Buhle, L., and Gerace, L. (1986). The nuclear lamina is a meshwork of intermediate-type filaments. Nature 323, 560-564. doi: 10.1038/ 323560a0

Ahmad, A., Enzlin, J. H., Bhagwat, N. R., Wijgers, N., Raams, A., Appledoorn, E., et al. (2010). Mislocalization of XPF-ERCC1 nuclease contributes to reduced DNA repair in XP-F patients. PLoS Genet. 6:e1000871. doi: 10.1371/journal. pgen. 1000871

Albuquerque, E. X., Barnard, E. A., Porter, C. W., and Warnick, J. E. (1974). The density of acetylcholine receptors and their sensitivity in the postsynaptic membrane of muscle endplates. Proc. Natl. Acad. Sci. U.S.A. 71, 2818-2822. doi: $10.1073 /$ pnas.71.7.2818

Anderson, M. J., and Cohen, M. W. (1977). Nerve-induced and spontaneous redistribution of acetylcholine receptors on cultured muscle cells. J. Physiol. 268, 757-773. doi: 10.1113/jphysiol.1977.sp011880 there is evidence for a beneficial effect of specific nutrients and dietary supplements on the aged neuromuscular system in humans. A recent review discussed potential mechanisms of promoting healthy neuromuscular aging by $\beta$-hydroxy$\beta$-methylbutyrate, creatine, dietary phospholipids, omega- 3 fatty acids, and vitamin D (Kougias et al., 2018). Additional clinical research investigating optimal dosages and durations of caloric restriction and nutritional intervention is needed to determine whether these effects can attenuate the aging process.

Examining the pathological mechanisms of neurodegenerative diseases with phenotypes similar to aging will help evaluate the molecular changes that underlie the structural and functional changes seen during aging. These include changes in active zone number and composition, NMJ innervation, and muscle mass. Also, mouse models of accelerated aging add value by identifying new pathways involved in aging. Importantly, the conserved beneficial effect in rodents, non-human primates, and humans supports the importance of caloric restriction and exercise for improving physical function in the elderly. Taken together, these strategies are likely to contribute to the development of interventions for preventing age-related neuromuscular dysfunction, sarcopenia, and frailty.

\section{AUTHOR CONTRIBUTIONS}

YB and HN contributed to the conception and writing of this review manuscript. Both authors contributed to the article and approved the submitted version.

\section{FUNDING}

This work was supported by the National Institute of Health (1R01AG051470 for HN) and Japan Society for the Promotion of Science (19K24690 for HN).

\section{ACKNOWLEDGMENTS}

We thank the topic editors for the invitation to this manuscript.

Anderson, R. M., and Weindruch, R. (2010). Metabolic reprogramming, caloric restriction and aging. Trends Endocrinol. Metab. 21, 134-141. doi: 10.1016/j. tem.2009.11.005

Anderson, R. M., and Weindruch, R. (2012). The caloric restriction paradigm: implications for healthy human aging. Am. J. Hum. Biol. 24, 101-106. doi: 10.1002/ajhb.22243

Andonian, M. H., and Fahim, M. A. (1988). Endurance exercise alters the morphology of fast- and slow-twitch rat neuromuscular junctions. Int. J. Sports Med. 9, 218-223. doi: 10.1055/s-2007-1025009

Apel, E. D., Glass, D. J., Moscoso, L. M., Yancopoulos, G. D., and Sanes, J. R. (1997). Rapsyn is required for MuSK signaling and recruits synaptic components to a MuSK-containing scaffold. Neuron 18, 623-635. doi: 10.1016/s0896-6273(00) 80303-7

Arizono, N., Koreto, O., Iwai, Y., Hidaka, T., and Takeoka, O. (1984). Morphometric analysis of human neuromuscular junction in different ages. Acta Pathol. Jpn. 34, 1243-1249. doi: 10.1111/j.1440-1827.1984.tb00551.x 
Atkin, J. D., Scott, R. L., West, J. M., Lopes, E., Quah, A. K., and Cheema, S. S. (2005). Properties of slow- and fast-twitch muscle fibres in a mouse model of amyotrophic lateral sclerosis. Neuromuscul. Disord. 15, 377-388. doi: 10.1016/ j.nmd.2005.02.005

Badawi, Y., and Nishimune, H. (2018). Presynaptic active zones of mammalian neuromuscular junctions: nanoarchitecture and selective impairments in aging. Neurosci. Res. 127, 78-88. doi: 10.1016/j.neures.2017.11.014

Baker, D. J., Jeganathan, K. B., Cameron, J. D., Thompson, M., Juneja, S., Kopecka, A., et al. (2004). BubR1 insufficiency causes early onset of aging-associated phenotypes and infertility in mice. Nat. Genet. 36, 744-749. doi: 10.1038/ ng1382

Baker, D. J., Perez-Terzic, C., Jin, F., Pitel, K. S., Niederlander, N. J., Jeganathan, K., et al. (2008). Opposing roles for p16Ink4a and p19Arf in senescence and ageing caused by BubR1 insufficiency. Nat. Cell Biol. 10, 825-836. doi: 10.1038/ ncb1744

Baker, D. J., Wijshake, T., Tchkonia, T., LeBrasseur, N. K., Childs, B. G., van de Sluis, B., et al. (2011). Clearance of p16Ink4a-positive senescent cells delays ageing-associated disorders. Nature 479, 232-236. doi: 10.1038/nature10600

Banker, B. Q., Kelly, S. S., and Robbins, N. (1983). Neuromuscular transmission and correlative morphology in young and old mice. J. Physiol. 339, 355-377. doi: 10.1113/jphysiol.1983.sp014721

Beeson, D., Higuchi, O., Palace, J., Cossins, J., Spearman, H., Maxwell, S., et al. (2006). Dok-7 mutations underlie a neuromuscular junction synaptopathy. Science 313, 1975-1978. doi: 10.1126/science.1130837

Bergo, M. O., Gavino, B., Ross, J., Schmidt, W. K., Hong, C., Kendall, L. V., et al. (2002). Zmpste24 deficiency in mice causes spontaneous bone fractures, muscle weakness, and a prelamin A processing defect. Proc. Natl. Acad. Sci. U.S.A. 99, 13049-13054. doi: 10.1073/pnas.192460799

Binks, S., Vincent, A., and Palace, J. (2016). Myasthenia gravis: a clinicalimmunological update. J. Neurol. 263, 826-834. doi: 10.1007/s00415-0157963-5

Boehm, I., Alhindi, A., Leite, A. S., Logie, C., Gibbs, A., Murray, O., et al. (2020). Comparative anatomy of the mammalian neuromuscular junction. J. Anat. 237, 827-836. doi: 10.1111/joa.13260

Bromberg, M. B., and Scott, D. M. (1994). Single fiber EMG reference values: reformatted in tabular form. AD HOC Committee of the AAEM single fiber special interest group. Muscle Nerve 17, 820-821. doi: 10.1002/mus.880170720

Brooks, K. J., Hill, M. D., Hockings, P. D., and Reid, D. G. (2004). MRI detects early hindlimb muscle atrophy in Gly93Ala superoxide dismutase-1 (G93A SOD1) transgenic mice, an animal model of familial amyotrophic lateral sclerosis. NMR Biomed. 17, 28-32. doi: 10.1002/nbm.861

Brown, R. H. (1995). Amyotrophic lateral sclerosis: recent insights from genetics and transgenic mice. Cell 80, 687-692. doi: 10.1016/0092-8674(95)90346-1

Cadore, E. L., Pinto, R. S., Bottaro, M., and Izquierdo, M. (2014). Strength and endurance training prescription in healthy and frail elderly. Aging Dis. 5, 183-195. doi: 10.14336/ad.2014.0500183

Caldwell, J. H. (2000). Clustering of sodium channels at the neuromuscular junction. Microsc. Res. Tech. 49, 84-89. doi: 10.1002/(SICI)10970029(20000401)49:1<84::AID-JEMT9<3.0.CO;2-E

Carrero, D., Soria-Valles, C., and Lopez-Otin, C. (2016). Hallmarks of progeroid syndromes: lessons from mice and reprogrammed cells. Dis. Model. Mech. 9, 719-735. doi: 10.1242/dmm.024711

Chai, R. J., Vukovic, J., Dunlop, S., Grounds, M. D., and Shavlakadze, T. (2011). Striking denervation of neuromuscular junctions without lumbar motoneuron loss in geriatric mouse muscle. PLoS One 6:e28090. doi: 10.1371/journal.pone. 0028090

Chan, Y. C., Suzuki, M., and Yamamoto, S. (1997). Dietary, anthropometric, hematological and biochemical assessment of the nutritional status of centenarians and elderly people in Okinawa, Japan. J. Am. Coll. Nutr. 16, 229-235. doi: 10.1080/07315724.1997.10718679

Chen, J., Mizushige, T., and Nishimune, H. (2012). Active zone density is conserved during synaptic growth but impaired in aged mice. J. Comp. Neurol. 520, 434-452. doi: 10.1002/cne.22764

Cheng, A., Morsch, M., Murata, Y., Ghazanfari, N., Reddel, S. W., and Phillips, W. D. (2013). Sequence of age-associated changes to the mouse neuromuscular junction and the protective effects of voluntary exercise. PLoS One 8:e67970. doi: 10.1371/journal.pone.0067970
Chiu, A. Y., Zhai, P., Dal Canto, M. C., Peters, T. M., Kwon, Y. W., Prattis, S. M., et al. (1995). Age-dependent penetrance of disease in a transgenic mouse model of familial amyotrophic lateral sclerosis. Mol. Cell Neurosci. 6, 349-362. doi: $10.1006 /$ mcne.1995.1027

Chugh, D., Iyer, C. C., Wang, X., Bobbili, P., Rich, M. M., and Arnold, W. D. (2020). Neuromuscular junction transmission failure is a late phenotype in aging mice. Neurobiol. Aging 86, 182-190. doi: 10.1016/j.neurobiolaging.2019.10.022

Civitarese, A. E., Carling, S., Heilbronn, L. K., Hulver, M. H., Ukropcova, B., Deutsch, W. A., et al. (2007). Calorie restriction increases muscle mitochondrial biogenesis in healthy humans. PLoS Med. 4:e76. doi: 10.1371/journal.pmed. 0040076

Clark, B. C. (2019). Neuromuscular changes with aging and sarcopenia. J. Frailty Aging 8, 7-9. doi: 10.14283/jfa.2018.35

Clark, D. O. (1996). The effect of walking on lower body disability among older blacks and whites. Am. J. Public Health 86, 57-61. doi: 10.2105/ajph.86.1.57

Collado, M., Blasco, M. A., and Serrano, M. (2007). Cellular senescence in cancer and aging. Cell 130, 223-233. doi: 10.1016/j.cell.2007.07.003

Conti-Fine, B. M., Milani, M., and Kaminski, H. J. (2006). Myasthenia gravis: past, present, and future. J. Clin. Invest. 116, 2843-2854. doi: 10.1172/JCI29894

Couteaux, R., and Pecot-Dechavassine, M. (1970). Synaptic vesicles and pouches at the level of "active zones" of the neuromuscular junction. C. R. Acad. Hebd. Seances Acad. Sci. D 271, 2346-2349.

Dadon-Nachum, M., Melamed, E., and Offen, D. (2011). The "dying-back" phenomenon of motor neurons in ALS. J. Mol. Neurosci. 43, 470-477. doi: 10.1007/s12031-010-9467-1

Dani, A., Huang, B., Bergan, J., Dulac, C., and Zhuang, X. (2010). Superresolution imaging of chemical synapses in the brain. Neuron 68, 843-856. doi: 10.1016/j. neuron.2010.11.021

De Sandre-Giovannoli, A., Bernard, R., Cau, P., Navarro, C., Amiel, J., Boccaccio, I., et al. (2003). Lamin a truncation in Hutchinson-Gilford progeria. Science 300:2055. doi: 10.1126/science.1084125

de Waard, M. C., van der Pluijm, I., Zuiderveen Borgesius, N., Comley, L. H., Haasdijk, E. D., Rijksen, Y., et al. (2010). Age-related motor neuron degeneration in DNA repair-deficient Erccl mice. Acta Neuropathol. 120, 461-475. doi: 10.1007/s00401-010-0715-9

DeChiara, T. M., Bowen, D. C., Valenzuela, D. M., Simmons, M. V., Poueymirou, W. T., Thomas, S., et al. (1996). The receptor tyrosine kinase MuSK is required for neuromuscular junction formation in vivo. Cell 85, 501-512. doi: 10.1016/ s0092-8674(00)81251-9

Dengler, R., Konstanzer, A., Kuther, G., Hesse, S., Wolf, W., and Struppler, A. (1990). Amyotrophic lateral sclerosis: macro-EMG and twitch forces of single motor units. Muscle Nerve 13, 545-550. doi: 10.1002/mus.880130612

Deschenes, M. R., Hurst, T. E., Ramser, A. E., and Sherman, E. G. (2013). Presynaptic to postsynaptic relationships of the neuromuscular junction are held constant across age and muscle fiber type. Dev. Neurobiol. 73, 744-753. doi: 10.1002/dneu.22095

Deschenes, M. R., Roby, M. A., Eason, M. K., and Harris, M. B. (2010). Remodeling of the neuromuscular junction precedes sarcopenia related alterations in myofibers. Exp. Gerontol. 45, 389-393. doi: 10.1016/j.exger.2010.03.007

Deschenes, M. R., Roby, M. A., and Glass, E. K. (2011). Aging influences adaptations of the neuromuscular junction to endurance training. Neuroscience 190, 56-66. doi: 10.1016/j.neuroscience.2011.05.070

Dobrowolny, G., Martini, M., Scicchitano, B. M., Romanello, V., Boncompagni, S., Nicoletti, C., et al. (2018). Muscle expression of SOD1(G93A) triggers the dismantlement of neuromuscular junction via PKC-Theta. Antioxid Redox Signal. 28, 1105-1119. doi: 10.1089/ars.2017.7054

Ehmann, N., Van De Linde, S., Alon, A., Ljaschenko, D., Keung, X. Z., Holm, T., et al. (2014). Quantitative super-resolution imaging of Bruchpilot distinguishes active zone states. Nat. Commun. 5:4650. doi: 10.1038/ncomms5650

Elchuri, S., Oberley, T. D., Qi, W., Eisenstein, R. S., Jackson Roberts, L., Van Remmen, H., et al. (2005). CuZnSOD deficiency leads to persistent and widespread oxidative damage and hepatocarcinogenesis later in life. Oncogene 24, 367-380. doi: 10.1038/sj.onc.1208207

Ellisman, M. H., Rash, J. E., Staehelin, L. A., and Porter, K. R. (1976). Studies of excitable membranes. II. A comparison of specializations at neuromuscular junctions and nonjunctional sarcolemmas of mammalian fast and slow twitch muscle fibers. J. Cell Biol. 68, 752-774. doi: 10.1083/jcb.68.3.752 
Engel, A. G., Lambert, E. H., and Gomez, M. R. (1977). A new myasthenic syndrome with end-plate acetylcholinesterase deficiency, small nerve terminals, and reduced acetylcholine release. Ann. Neurol. 1, 315-330. doi: 10.1002/ana. 410010403

Engel, A. G., Shen, X. M., Selcen, D., and Sine, S. M. (2010). What have we learned from the congenital myasthenic syndromes. J. Mol. Neurosci. 40, 143-153. doi: 10.1007/s12031-009-9229-0

Engel, A. G., Shen, X. M., Selcen, D., and Sine, S. M. (2015). Congenital myasthenic syndromes: pathogenesis, diagnosis, and treatment. Lancet Neurol. 14:461. doi: 10.1016/S1474-4422(15)00010-1

Eriksson, M., Brown, W. T., Gordon, L. B., Glynn, M. W., Singer, J., Scott, L., et al. (2003). Recurrent de novo point mutations in lamin A cause HutchinsonGilford progeria syndrome. Nature 423, 293-298. doi: 10.1038/nature01629

Fahim, M. A. (1997). Endurance exercise modulates neuromuscular junction of C57BL/6NNia aging mice. J. Appl. Physiol. (1985) 83, 59-66. doi: 10.1152/jappl. 1997.83.1.59

Fahim, M. A., Holley, J. A., and Robbins, N. (1983). Scanning and light microscopic study of age changes at a neuromuscular junction in the mouse. J. Neurocytol. 12, 13-25. doi: 10.1007/Bf01148085

Fahim, M. A., and Robbins, N. (1982). Ultrastructural studies of young and old mouse neuromuscular junctions. J. Neurocytol. 11, 641-656. doi: 10.1007/ bf01262429

Ferrucci, L., Izmirlian, G., Leveille, S., Phillips, C. L., Corti, M. C., Brock, D. B., et al. (1999). Smoking, physical activity, and active life expectancy. Am. J. Epidemiol. 149, 645-653. doi: 10.1093/oxfordjournals.aje.a009865

Fertuck, H. C., and Salpeter, M. M. (1974). Localization of acetylcholine receptor by 125I-labeled alpha-bungarotoxin binding at mouse motor endplates. Proc. Natl. Acad. Sci. U.S.A. 71, 1376-1378. doi: 10.1073/pnas.71.4.1376

Fertuck, H. C., and Salpeter, M. M. (1976). Quantitation of junctional and extrajunctional acetylcholine receptors by electron microscope autoradiography after 125I-alpha-bungarotoxin binding at mouse neuromuscular junctions. J. Cell Biol. 69, 144-158. doi: 10.1083/jcb.69.1.144

Fischer, L. R., Culver, D. G., Tennant, P., Davis, A. A., Wang, M., CastellanoSanchez, A., et al. (2004). Amyotrophic lateral sclerosis is a distal axonopathy: evidence in mice and man. Exp. Neurol. 185, 232-240. doi: 10.1016/j.expneurol. 2003.10.004

Fischer, L. R., Igoudjil, A., Magrane, J., Li, Y., Hansen, J. M., Manfredi, G., et al. (2011). SOD1 targeted to the mitochondrial intermembrane space prevents motor neuropathy in the Sod1 knockout mouse. Brain 134(Pt 1), 196-209. doi: 10.1093/brain/awq314

Fischer, L. R., Li, Y., Asress, S. A., Jones, D. P., and Glass, J. D. (2012). Absence of SOD1 leads to oxidative stress in peripheral nerve and causes a progressive distal motor axonopathy. Exp. Neurol. 233, 163-171. doi: 10.1016/j.expneurol. 2011.09.020

Flink, M. T., and Atchison, W. D. (2003). Ca2+ channels as targets of neurological disease: Lambert-Eaton Syndrome and other $\mathrm{Ca} 2+$ channelopathies. J. Bioenerg. Biomembr. 35, 697-718. doi: 10.1023/b:jobb.0000008033.02320.10

Flood, D. G., Reaume, A. G., Gruner, J. A., Hoffman, E. K., Hirsch, J. D., Lin, Y. G., et al. (1999). Hindlimb motor neurons require $\mathrm{Cu} / \mathrm{Zn}$ superoxide dismutase for maintenance of neuromuscular junctions. Am. J. Pathol. 155, 663-672. doi: 10.1016/S0002-9440(10)65162-0

Folgueras, A. R., Freitas-Rodriguez, S., Velasco, G., and Lopez-Otin, C. (2018). Mouse models to disentangle the hallmarks of human aging. Circ. Res. 123, 905-924. doi: 10.1161/CIRCRESAHA.118.312204

Fontana, L., Partridge, L., and Longo, V. D. (2010). Extending healthy life spanfrom yeast to humans. Science 328, 321-326. doi: 10.1126/science.1172539

Frank, E., and Fischbach, G. D. (1979). Early events in neuromuscular junction formation in vitro: induction of acetylcholine receptor clusters in the postsynaptic membrane and morphology of newly formed synapses. J. Cell Biol. 83, 143-158. doi: $10.1083 /$ jcb.83.1.143

Fried, L. P., Tangen, C. M., Walston, J., Newman, A. B., Hirsch, C., Gottdiener, J., et al. (2001). Frailty in older adults: evidence for a phenotype. J. Gerontol. A Biol. Sci. Med. Sci. 56, M146-M156. doi: 10.1093/gerona/56.3.m146

Frontera, W. R., Hughes, V. A., Fielding, R. A., Fiatarone, M. A., Evans, W. J., and Roubenoff, R. (2000). Aging of skeletal muscle: a 12-yr longitudinal study. J. Appl. Physiol. (1985) 88, 1321-1326. doi: 10.1152/jappl.2000.88.4.1321

Fukunaga, H., Engel, A. G., Lang, B., Newsom-Davis, J., and Vincent, A. (1983). Passive transfer of Lambert-Eaton myasthenic syndrome with IgG from man to mouse depletes the presynaptic membrane active zones. Proc. Natl. Acad. Sci. U.S.A. 80, 7636-7640.

Fukunaga, H., Engel, A. G., Osame, M., and Lambert, E. H. (1982). Paucity and disorganization of presynaptic membrane active zones in the lamberteaton myasthenic syndrome. Muscle Nerve 5, 686-697. doi: 10.1002/mus.8800 50905

Fukuoka, T., Engel, A. G., Lang, B., Newsom-Davis, J., Prior, C., and Wray, D. W. (1987). Lambert-Eaton myasthenic syndrome: I. Early morphological effects of IgG on the presynaptic membrane active zones. Ann. Neurol. 22, 193-199. doi: 10.1002/ana.410220203

Fulle, S., Protasi, F., Di Tano, G., Pietrangelo, T., Beltramin, A., Boncompagni, S., et al. (2004). The contribution of reactive oxygen species to sarcopenia and muscle ageing. Exp. Gerontol. 39, 17-24. doi: 10.1016/j.exger.2003.09.012

Galea, V. (1996). Changes in motor unit estimates with aging. J. Clin. Neurophysiol. 13, 253-260. doi: 10.1097/00004691-199605000-00010

Gambino, D. R., Malmgren, L. T., and Gacek, R. R. (1990). Age-related changes in the neuromuscular junctions in the human posterior cricoarytenoid muscles: a quantitative study. Laryngoscope 100, 262-268. doi: 10.1288/00005537199003000-00010

Gao, N., Zhao, K., Cao, Y., Ren, X., Jing, H., Xing, G., et al. (2020). A role of lamin $\mathrm{A} / \mathrm{C}$ in preventing neuromuscular junction decline in mice. J. Neurosci. 40, 7203-7203. doi: 10.1523/JNEUROSCI.0443-20.2020

Ghosh, S., and Zhou, Z. (2015). SIRTain regulators of premature senescence and accelerated aging. Protein Cell 6, 322-333. doi: 10.1007/s13238-015-0149-1

Gilhus, N. E., and Verschuuren, J. J. (2015). Myasthenia gravis: subgroup classification and therapeutic strategies. Lancet Neurol. 14, 1023-1036. doi: 10.1016/S1474-4422(15)00145-3

Gonzalez-Freire, M., de Cabo, R., Studenski, S. A., and Ferrucci, L. (2014). The neuromuscular junction: aging at the crossroad between nerves and muscle. Front. Aging Neurosci. 6:208. doi: 10.3389/fnagi.2014.00208

Greising, S. M., Call, J. A., Lund, T. C., Blazar, B. R., Tolar, J., and Lowe, D. A. (2012). Skeletal muscle contractile function and neuromuscular performance in Zmpste24 -/- mice, a murine model of human progeria. Age (Dordr) 34, 805-819. doi: 10.1007/s11357-011-9281-x

Gurney, M. E., Pu, H., Chiu, A. Y., Dal Canto, M. C., Polchow, C. Y., Alexander, D. D., et al. (1994). Motor neuron degeneration in mice that express a human $\mathrm{Cu}, \mathrm{Zn}$ superoxide dismutase mutation. Science 264, 1772-1775. doi: 10.1126/ science.8209258

Hallock, P. T., Xu, C. F., Park, T. J., Neubert, T. A., Curran, T., and Burden, S. J. (2010). Dok-7 regulates neuromuscular synapse formation by recruiting Crk and Crk-L. Genes Dev. 24, 2451-2461. doi: 10.1101/gad.1977710

Hansen, M., Taubert, S., Crawford, D., Libina, N., Lee, S. J., and Kenyon, C. (2007). Lifespan extension by conditions that inhibit translation in Caenorhabditis elegans. Aging Cell 6, 95-110. doi: 10.1111/j.1474-9726.2006.00267.x

Harkema, L., Youssef, S. A., and de Bruin, A. (2016). Pathology of mouse models of accelerated aging. Vet. Pathol. 53, 366-389. doi: 10.1177/030098581562 5169

Harlow, M. L., Ress, D., Stoschek, A., Marshall, R. M., and McMahan, U. J. (2001). The architecture of active zone material at the frog's neuromuscular junction. Nature 409, 479-484. doi: 10.1038/35054000

Harlow, M. L., Szule, J. A., Xu, J., Jung, J. H., Marshall, R. M., and McMahan, U. J. (2013). Alignment of synaptic vesicle macromolecules with the macromolecules in active zone material that direct vesicle docking. PLoS One 8:e69410. doi: 10.1371/journal.pone.0069410

Hegedus, J., Putman, C. T., and Gordon, T. (2007). Time course of preferential motor unit loss in the SOD1 G93A mouse model of amyotrophic lateral sclerosis. Neurobiol. Dis. 28, 154-164. doi: 10.1016/j.nbd.2007.07.003

Hegedus, J., Putman, C. T., Tyreman, N., and Gordon, T. (2008). Preferential motor unit loss in the SOD1 G93A transgenic mouse model of amyotrophic lateral sclerosis. J. Physiol. 586, 3337-3351. doi: 10.1113/jphysiol.2007.149286

Heilbronn, L. K., de Jonge, L., Frisard, M. I., DeLany, J. P., Larson-Meyer, D. E., Rood, J., et al. (2006). Effect of 6-month calorie restriction on biomarkers of longevity, metabolic adaptation, and oxidative stress in overweight individuals: a randomized controlled trial. JAMA 295, 1539-1548. doi: 10.1001/jama.295.13. 1539

Higuchi, O., Hamuro, J., Motomura, M., and Yamanashi, Y. (2011). Autoantibodies to low-density lipoprotein receptor-related protein 4 in myasthenia gravis. Ann. Neurol. 69, 418-422. doi: 10.1002/ana.22312 
Ho, Y. S., Gargano, M., Cao, J., Bronson, R. T., Heimler, I., and Hutz, R. J. (1998). Reduced fertility in female mice lacking copper-zinc superoxide dismutase. J. Biol. Chem. 273, 7765-7769. doi: 10.1074/jbc.273.13.7765

Hoeijmakers, J. H. (2009). DNA damage, aging, and cancer. N. Engl. J. Med. 361, 1475-1485. doi: 10.1056/NEJMra0804615

Hong, S. J., and Chang, C. C. (1989). Use of geographutoxin II (mu-conotoxin) for the study of neuromuscular transmission in mouse. Br. J. Pharmacol. 97, 934-940. doi: 10.1111/j.1476-5381.1989.tb12034.x

Hourigan, M. L., McKinnon, N. B., Johnson, M., Rice, C. L., Stashuk, D. W., and Doherty, T. J. (2015). Increased motor unit potential shape variability across consecutive motor unit discharges in the tibialis anterior and vastus medialis muscles of healthy older subjects. Clin. Neurophysiol. 126, 2381-2389. doi: 10.1016/j.clinph.2015.02.002

Huijbers, M. G., Zhang, W., Klooster, R., Niks, E. H., Friese, M. B., Straasheijm, K. R., et al. (2013). MuSK IgG4 autoantibodies cause myasthenia gravis by inhibiting binding between MuSK and Lrp4. Proc. Natl. Acad. Sci. U.S.A. 110, 20783-20788. doi: 10.1073/pnas.1313944110

Hunter, D. D., Shah, V., Merlie, J. P., and Sanes, J. R. (1989). A laminin-like adhesive protein concentrated in the synaptic cleft of the neuromuscular junction. Nature 338, 229-234. doi: 10.1038/338229a0

Jahn, R., and Scheller, R. H. (2006). SNAREs-engines for membrane fusion. Nat. Rev. Mol. Cell Biol. 7, 631-643. doi: 10.1038/nrm2002

Jang, Y. C., Lustgarten, M. S., Liu, Y., Muller, F. L., Bhattacharya, A., Liang, H., et al. (2010). Increased superoxide in vivo accelerates age-associated muscle atrophy through mitochondrial dysfunction and neuromuscular junction degeneration. FASEB J. 24, 1376-1390. doi: 10.1096/fj.09-146308

Janssen, I., Heymsfield, S. B., Wang, Z. M., and Ross, R. (2000). Skeletal muscle mass and distribution in 468 men and women aged 18-88 yr. J. Appl. Physiol. (1985) 89, 81-88. doi: 10.1152/jappl.2000.89.1.81

Jaspers, N. G., Raams, A., Silengo, M. C., Wijgers, N., Niedernhofer, L. J., Robinson, A. R., et al. (2007). First reported patient with human ERCC1 deficiency has cerebro-oculo-facio-skeletal syndrome with a mild defect in nucleotide excision repair and severe developmental failure. Am. J. Hum. Genet. 80, 457-466. doi: $10.1086 / 512486$

Jones, R. A., Harrison, C., Eaton, S. L., Llavero Hurtado, M., Graham, L. C., Alkhammash, L., et al. (2017). Cellular and molecular anatomy of the human neuromuscular junction. Cell Rep. 21, 2348-2356. doi: 10.1016/j.celrep.2017. 11.008

Jung, J. H., Szule, J. A., Stouder, K., Marshall, R. M., and McMahan, U. J. (2018). Active zone material-directed orientation, docking, and fusion of dense core vesicles alongside synaptic vesicles at neuromuscular junctions. Front. Neuroanat. 12:72. doi: 10.3389/fnana.2018.00072

Kaeberlein, M., Powers, R. W. III, Steffen, K. K., Westman, E. A., Hu, D., Dang, N., et al. (2005). Regulation of yeast replicative life span by TOR and Sch9 in response to nutrients. Science 310, 1193-1196. doi: 10.1126/science.1115535

Kapahi, P., Zid, B. M., Harper, T., Koslover, D., Sapin, V., and Benzer, S. (2004). Regulation of lifespan in Drosophila by modulation of genes in the TOR signaling pathway. Curr. Biol. 14, 885-890. doi: 10.1016/j.cub.2004.03.059

Kawamura, Y., O’Brien, P., Okazaki, H., and Dyck, P. J. (1977). Lumbar motoneurons of man II: the number and diameter distribution of large- and intermediate-diameter cytons in "motoneuron columns" of spinal cord of man. J. Neuropathol. Exp. Neurol. 36, 861-870. doi: 10.1097/00005072-19770900000010

Kelly, S. S., and Robbins, N. (1983). Progression of age changes in synaptic transmission at mouse neuromuscular junctions. J. Physiol. 343, 375-383. doi: 10.1113/jphysiol.1983.sp014898

Kennel, P. F., Finiels, F., Revah, F., and Mallet, J. (1996). Neuromuscular function impairment is not caused by motor neurone loss in FALS mice: an electromyographic study. Neuroreport 7, 1427-1431. doi: 10.1097/00001756199605310-00021

Kim, N., Stiegler, A. L., Cameron, T. O., Hallock, P. T., Gomez, A. M., Huang, J. H., et al. (2008). Lrp4 is a receptor for Agrin and forms a complex with MuSK. Cell 135, 334-342. doi: 10.1016/j.cell.2008.10.002

Kittel, R. J., Wichmann, C., Rasse, T. M., Fouquet, W., Schmidt, M., Schmid, A., et al. (2006). Bruchpilot promotes active zone assembly, Ca2+ channel clustering, and vesicle release. Science 312, 1051-1054. doi: 10.1126/science. 1126308
Klein, C. S., Marsh, G. D., Petrella, R. J., and Rice, C. L. (2003). Muscle fiber number in the biceps brachii muscle of young and old men. Muscle Nerve 28, 62-68. doi: $10.1002 /$ mus. 10386

Kougias, D. G., Das, T., Perez, A. B., and Pereira, S. L. (2018). A role for nutritional intervention in addressing the aging neuromuscular junction. Nutr. Res. 53, 1-14. doi: 10.1016/j.nutres.2018.02.006

Lambert, E. H., and Elmqvist, D. (1971). Quantal components of end-plate potentials in the myasthenic syndrome. Ann. N. Y. Acad. Sci. 183, 183-199. doi: 10.1111/j.1749-6632.1971.tb30750.x

Larsson, L. (1995). Motor units: remodeling in aged animals. J. Gerontol. A Biol. Sci. Med. Sci. 50, 91-95. doi: 10.1093/gerona/50a.special_issue.91

Lavin, K. M., Roberts, B. M., Fry, C. S., Moro, T., Rasmussen, B. B., and Bamman, M. M. (2019). The importance of resistance exercise training to combat neuromuscular aging. Physiology (Bethesda) 34, 112-122. doi: 10.1152/physiol. 00044.2018

Lee, Y., Rudell, J., and Ferns, M. (2009). Rapsyn interacts with the muscle acetylcholine receptor via alpha-helical domains in the alpha, beta, and epsilon subunit intracellular loops. Neuroscience 163, 222-232. doi: 10.1016/j. neuroscience.2009.05.057

Leung, G. K., Schmidt, W. K., Bergo, M. O., Gavino, B., Wong, D. H., Tam, A., et al. (2001). Biochemical studies of Zmpste24-deficient mice. J. Biol. Chem. 276, 29051-29058. doi: 10.1074/jbc.M102908200

Lexell, J. (1995). Human aging, muscle mass, and fiber type composition. J. Gerontol. A Biol. Sci. Med. Sci. 50, 11-16. doi: 10.1093/gerona/50a.special_ issue. 11

Lexell, J., and Downham, D. Y. (1991). The occurrence of fibre-type grouping in healthy human muscle: a quantitative study of cross-sections of whole vastus lateralis from men between 15 and 83 years. Acta Neuropathol. 81, 377-381. doi: $10.1007 /$ bf00293457

Lexell, J., Henriksson-Larsen, K., Winblad, B., and Sjostrom, M. (1983). Distribution of different fiber types in human skeletal muscles: effects of aging studied in whole muscle cross sections. Muscle Nerve 6, 588-595. doi: 10.1002/ mus. 880060809

Lexell, J., Taylor, C. C., and Sjostrom, M. (1988). What is the cause of the ageing atrophy? Total number, size and proportion of different fiber types studied in whole vastus lateralis muscle from 15- to 83 -year-old men. J. Neurol. Sci. 84, 275-294.

Li, L., Xiong, W. C., and Mei, L. (2018). Neuromuscular junction formation, aging, and disorders. Annu. Rev. Physiol. 80, 159-188. doi: 10.1146/annurev-physiol022516-034255

Li, Y., Lee, Y., and Thompson, W. J. (2011). Changes in aging mouse neuromuscular junctions are explained by degeneration and regeneration of muscle fiber segments at the synapse. J. Neurosci. 31, 14910-14919. doi: 10. 1523/JNEUROSCI.3590-11.2011

Lindboe, C. F., and Torvik, A. (1982). The effects of ageing, cachexia and neoplasms on striated muscle. Quantitative histological and histochemical observations on an autopsy material. Acta Neuropathol. 57, 85-92. doi: 10.1007/bf00685374

Lopez, P., Pinto, R. S., Radaelli, R., Rech, A., Grazioli, R., Izquierdo, M., et al. (2018). Benefits of resistance training in physically frail elderly: a systematic review. Aging Clin. Exp. Res. 30, 889-899. doi: 10.1007/s40520-017-0863-z

Loutrari, H., Kokla, A., and Tzartos, S. J. (1992). Passive transfer of experimental myasthenia gravis via antigenic modulation of acetylcholine receptor. Eur. J. Immunol. 22, 2449-2452. doi: 10.1002/eji.1830220939

Manini, T. M., Hong, S. L., and Clark, B. C. (2013). Aging and muscle: a neuron's perspective. Curr. Opin. Clin. Nutr. Metab. Care 16, 21-26. doi: 10.1097/MCO. 0b013e32835b5880

Marcuzzo, S., Zucca, I., Mastropietro, A., de Rosbo, N. K., Cavalcante, P., Tartari, S., et al. (2011). Hind limb muscle atrophy precedes cerebral neuronal degeneration in G93A-SOD1 mouse model of amyotrophic lateral sclerosis: a longitudinal MRI study. Exp. Neurol. 231, 30-37. doi: 10.1016/j.expneurol.2011. 05.007

Martin, G. M. (1978). Genetic syndromes in man with potential relevance to the pathobiology of aging. Birth Defects Orig. Artic Ser. 14, 5-39.

Maselli, R. A., Ng, J. J., Anderson, J. A., Cagney, O., Arredondo, J., Williams, C., et al. (2009). Mutations in LAMB2 causing a severe form of synaptic congenital myasthenic syndrome. J. Med. Genet. 46, 203-208. doi: 10.1136/jmg. 2008.063693 
McComas, A. J., Fawcett, P. R., Campbell, M. J., and Sica, R. E. (1971). Electrophysiological estimation of the number of motor units within a human muscle. J. Neurol. Neurosurg. Psychiatry 34, 121-131. doi: 10.1136/jnnp.34. 2.121

McFadden, S. L., Ding, D., Reaume, A. G., Flood, D. G., and Salvi, R. J. (1999). Age-related cochlear hair cell loss is enhanced in mice lacking copper/zinc superoxide dismutase. Neurobiol. Aging 20, 1-8. doi: 10.1016/s0197-4580(99) 00018-4

McKiernan, S. H., Colman, R. J., Lopez, M., Beasley, T. M., Aiken, J. M., Anderson, R. M., et al. (2011). Caloric restriction delays aging-induced cellular phenotypes in rhesus monkey skeletal muscle. Exp. Gerontol. 46, 23-29. doi: 10.1016/j.exger. 2010.09.011

McNeil, C. J., Doherty, T. J., Stashuk, D. W., and Rice, C. L. (2005). Motor unit number estimates in the tibialis anterior muscle of young, old, and very old men. Muscle Nerve 31, 461-467. doi: 10.1002/mus.20276

Mitchell, W. K., Williams, J., Atherton, P., Larvin, M., Lund, J., and Narici, M. (2012). Sarcopenia, dynapenia, and the impact of advancing age on human skeletal muscle size and strength; a quantitative review. Front. Physiol. 3:260. doi: $10.3389 /$ fphys.2012.00260

Mittal, K. R., and Logmani, F. H. (1987). Age-related reduction in 8th cervical ventral nerve root myelinated fiber diameters and numbers in man. J. Gerontol. 42, 8-10. doi: 10.1093/geronj/42.1.8

Mori, S., Kubo, S., Akiyoshi, T., Yamada, S., Miyazaki, T., Hotta, H., et al. (2012). Antibodies against muscle-specific kinase impair both presynaptic and postsynaptic functions in a murine model of myasthenia gravis. Am. J. Pathol. 180, 798-810. doi: 10.1016/j.ajpath.2011.10.031

Mori, S., Motohashi, N., Takashima, R., Kishi, M., Nishimune, H., and Shigemoto, K. (2017). Immunization of mice with LRP4 induces myasthenia similar to MuSK-associated myasthenia gravis. Exp. Neurol. 297, 158-167. doi: 10.1016/ j.expneurol.2017.08.006

Mosole, S., Carraro, U., Kern, H., Loefler, S., Fruhmann, H., Vogelauer, M., et al. (2014). Long-term high-level exercise promotes muscle reinnervation with age. J. Neuropathol. Exp. Neurol. 73, 284-294. doi: 10.1097/nen.0000000000000032

Most, J., Tosti, V., Redman, L. M., and Fontana, L. (2017). Calorie restriction in humans: an update. Ageing Res. Rev. 39, 36-45. doi: 10.1016/j.arr.2016.08.005

Muller, F. L., Song, W., Liu, Y., Chaudhuri, A., Pieke-Dahl, S., Strong, R., et al. (2006). Absence of CuZn superoxide dismutase leads to elevated oxidative stress and acceleration of age-dependent skeletal muscle atrophy. Free Radic. Biol. Med. 40, 1993-2004. doi: 10.1016/j.freeradbiomed.2006.01.036

Nagwaney, S., Harlow, M. L., Jung, J. H., Szule, J. A., Ress, D., Xu, J., et al. (2009). Macromolecular connections of active zone material to docked synaptic vesicles and presynaptic membrane at neuromuscular junctions of mouse. J. Comp. Neurol. 513, 457-468. doi: 10.1002/cne.21975

Nishimune, H., Badawi, Y., Mori, S., and Shigemoto, K. (2016). Dual-color STED microscopy reveals a sandwich structure of Bassoon and Piccolo in active zones of adult and aged mice. Sci. Rep. 6:27935. doi: 10.1038/srep27935

Nishimune, H., Numata, T., Chen, J., Aoki, Y., Wang, Y., Starr, M. P., et al. (2012). Active zone protein Bassoon co-localizes with presynaptic calcium channel, modifies channel function, and recovers from aging related loss by exercise. PLoS One 7:e38029. doi: 10.1371/journal.pone.0038029

Nishimune, H., Sanes, J. R., and Carlson, S. S. (2004). A synaptic laminin-calcium channel interaction organizes active zones in motor nerve terminals. Nature 432, 580-587. doi: 10.1038/nature03112

Noakes, P. G., Gautam, M., Mudd, J., Sanes, J. R., and Merlie, J. P. (1995). Aberrant differentiation of neuromuscular junctions in mice lacking s-laminin/laminin beta2. Nature 374:258. doi: 10.1038/374258a0

Oda, K. (1984). Age changes of motor innervation and acetylcholine receptor distribution on human skeletal muscle fibres. J. Neurol. Sci. 66, 327-338. doi: 10.1016/0022-510x(84)90021-2

Okada, K., Inoue, A., Okada, M., Murata, Y., Kakuta, S., Jigami, T., et al. (2006). The muscle protein Dok-7 is essential for neuromuscular synaptogenesis. Science 312, 1802-1805. doi: 10.1126/science.1127142

Otsuka, K., Ito, M., Ohkawara, B., Masuda, A., Kawakami, Y., Sahashi, K., et al. (2015). Collagen Q and anti-MuSK autoantibody competitively suppress agrin/LRP4/MuSK signaling. Sci. Rep. 5:13928. doi: 10.1038/srep13928

Papadopoli, D., Boulay, K., Kazak, L., Pollak, M., Mallette, F., Topisirovic, I., et al. (2019). mTOR as a central regulator of lifespan and aging. F1000Res 8:998. doi: 10.12688/f1000research.17196.1
Park, K. H. (2015). Mechanisms of muscle denervation in aging: insights from a mouse model of amyotrophic lateral sclerosis. Aging Dis. 6, 380-389. doi: 10.14336/AD.2015.0506

Patton, B. L., Cunningham, J. M., Thyboll, J., Kortesmaa, J., Westerblad, H., Edstrom, L., et al. (2001). Properly formed but improperly localized synaptic specializations in the absence of laminin alpha4. Nat. Neurosci. 4, 597-604. doi: $10.1038 / 88414$

Pestronk, A., Drachman, D. B., and Self, S. G. (1985). Measurement of junctional acetylcholine receptors in myasthenia gravis: clinical correlates. Muscle Nerve 8, 245-251. doi: 10.1002/mus.880080311

Phillips, J. P., Campbell, S. D., Michaud, D., Charbonneau, M., and Hilliker, A. J. (1989). Null mutation of copper/zinc superoxide dismutase in Drosophila confers hypersensitivity to paraquat and reduced longevity. Proc. Natl. Acad. Sci. U.S.A. 86, 2761-2765. doi: 10.1073/pnas.86.8.2761

Phillips, W. D., and Vincent, A. (2016). Pathogenesis of myasthenia gravis: update on disease types, models, and mechanisms. F1000Res 5:1513. doi: 10.12688/ f1000research.8206.1

Piasecki, M., Ireland, A., Stashuk, D., Hamilton-Wright, A., Jones, D. A., and McPhee, J. S. (2016). Age-related neuromuscular changes affecting human vastus lateralis. J. Physiol. 594, 4525-4536. doi: 10.1113/JP271087

Power, G. A., Allen, M. D., Gilmore, K. J., Stashuk, D. W., Doherty, T. J., Hepple, R. T., et al. (2016). Motor unit number and transmission stability in octogenarian world class athletes: can age-related deficits be outrun? J. Appl. Physiol. 121, 1013-1020. doi: 10.1152/japplphysiol.00149.2016

Power, G. A., Dalton, B. H., Behm, D. G., Doherty, T. J., Vandervoort, A. A., and Rice, C. L. (2012). Motor unit survival in lifelong runners is muscle dependent. Med. Sci. Sports Exerc. 44, 1235-1242. doi: 10.1249/MSS.0b013e318249953c

Power, G. A., Dalton, B. H., Behm, D. G., Vandervoort, A. A., Doherty, T. J., and Rice, C. L. (2010). Motor unit number estimates in masters runners: use it or lose it? Med. Sci. Sports Exerc. 42, 1644-1650. doi: 10.1249/MSS. 0b013e3181d6f9e9

Redman, L. M., Smith, S. R., Burton, J. H., Martin, C. K., Il'yasova, D., and Ravussin, E. (2018). Metabolic slowing and reduced oxidative damage with sustained caloric restriction support the rate of living and oxidative damage theories of aging. Cell Metab. 27, 805-815.e4. doi: 10.1016/j.cmet.2018.02.019

Rocha, M. C., Pousinha, P. A., Correia, A. M., Sebastiao, A. M., and Ribeiro, J. A. (2013). Early changes of neuromuscular transmission in the SOD1(G93A) mice model of ALS start long before motor symptoms onset. PLoS One 8:e73846. doi: 10.1371/journal.pone.0073846

Rosato Siri, M. D., and Uchitel, O. D. (1999). Calcium channels coupled to neurotransmitter release at neonatal rat neuromuscular junctions. J Physiol 514(Pt 2), 533-540. doi: 10.1111/j.1469-7793.1999.533ae.x

Rosen, D. R., Siddique, T., Patterson, D., Figlewicz, D. A., Sapp, P., Hentati, A., et al. (1993). Mutations in $\mathrm{Cu} / \mathrm{Zn}$ superoxide dismutase gene are associated with familial amyotrophic lateral sclerosis. Nature 362, 59-62. doi: 10.1038/ 362059a0

Roth, G. S., Ingram, D. K., Black, A., and Lane, M. A. (2000). Effects of reduced energy intake on the biology of aging: the primate model. Eur. J. Clin. Nutr. 54(Suppl. 3), S15-S20.

Rothbart, H. B. (1937). Myasthenia gravis in children: its familial incidence. J. Am. Med. Assoc. 108, 715-717. doi: 10.1001/jama.1937.02780090027008

Roubenoff, R. (2000). Sarcopenia and its implications for the elderly. Eur. J. Clin. Nutr. 54(Suppl. 3), S40-S47.

Rowan, S. L., Purves-Smith, F. M., Solbak, N. M., and Hepple, R. T. (2011). Accumulation of severely atrophic myofibers marks the acceleration of sarcopenia in slow and fast twitch muscles. Exp. Gerontol. 46, 660-669. doi: 10.1016/j.exger.2011.03.005

Ruff, R. L., and Lennon, V. A. (2008). How myasthenia gravis alters the safety factor for neuromuscular transmission. J. Neuroimmunol. 201-202, 13-20. doi: 10.1016/j.jneuroim.2008.04.038

Salmon, A. B., Richardson, A., and Perez, V. I. (2010). Update on the oxidative stress theory of aging: does oxidative stress play a role in aging or healthy aging? Free Radic. Biol. Med. 48, 642-655. doi: 10.1016/j.freeradbiomed.2009.12.015

Salpeter, M. M., and Loring, R. H. (1985). Nicotinic acetylcholine receptors in vertebrate muscle: properties, distribution and neural control. Prog. Neurobiol. 25, 297-325. doi: 10.1016/0301-0082(85)90018-8

Sanchez, R. J., Srinivasan, C., Munroe, W. H., Wallace, M. A., Martins, J., Kao, T. Y., et al. (2005). Exogenous manganous ion at millimolar levels rescues all known 
dioxygen-sensitive phenotypes of yeast lacking CuZnSOD. J. Biol. Inorg. Chem. 10, 913-923. doi: 10.1007/s00775-005-0044-y

Sanes, J. R., and Hall, Z. W. (1979). Antibodies that bind specifically to synaptic sites on muscle fiber basal lamina. J. Cell Biol. 83(Pt 1), 357-370. doi: 10.1083/ jcb.83.2.357

Sanes, J. R., and Lichtman, J. W. (2001). Induction, assembly, maturation and maintenance of a postsynaptic apparatus. Nat. Rev. Neurosci. 2, 791-805. doi: $10.1038 / 35097557$

Sanjak, M., Brinkmann, J., Belden, D. S., Roelke, K., Waclawik, A., Neville, H. E., et al. (2001). Quantitative assessment of motor fatigue in amyotrophic lateral sclerosis. J. Neurol. Sci. 191, 55-59.

Sataranatarajan, K., Qaisar, R., Davis, C., Sakellariou, G. K., Vasilaki, A., Zhang, Y., et al. (2015). Neuron specific reduction in CuZnSOD is not sufficient to initiate a full sarcopenia phenotype. Redox Biol. 5, 140-148. doi: 10.1016/j.redox.2015. 04.005

Saxton, R. A., and Sabatini, D. M. (2017). mTOR Signaling in Growth, Metabolism, and Disease. Cell 168, 960-976. doi: 10.1016/j.cell.2017.02.004

Scaffidi, P., and Misteli, T. (2006). Lamin A-dependent nuclear defects in human aging. Science 312, 1059-1063. doi: 10.1126/science.1127168

Shefner, J. M., Reaume, A. G., Flood, D. G., Scott, R. W., Kowall, N. W., Ferrante, R. J., et al. (1999). Mice lacking cytosolic copper/zinc superoxide dismutase display a distinctive motor axonopathy. Neurology 53, 1239-1246. doi: 10.1212/ wnl.53.6.1239

Sheth, K. A., Iyer, C. C., Wier, C. G., Crum, A. E., Bratasz, A., Kolb, S. J., et al. (2018). Muscle strength and size are associated with motor unit connectivity in aged mice. Neurobiol. Aging 67, 128-136. doi: 10.1016/j.neurobiolaging.2018.03.016

Shi, Y., Ivannikov, M. V., Walsh, M. E., Liu, Y., Zhang, Y., Jaramillo, C. A., et al. (2014). The lack of CuZnSOD leads to impaired neurotransmitter release, neuromuscular junction destabilization and reduced muscle strength in mice. PLoS One 9:e100834. doi: 10.1371/journal.pone.0100834

Shigemoto, K., Kubo, S., Maruyama, N., Hato, N., Yamada, H., Jie, C., et al. (2006). Induction of myasthenia by immunization against muscle-specific kinase. J. Clin. Invest. 116, 1016-1024. doi: 10.1172/jci21545

Shigemoto, K., Kubo, S., Mori, S., Yamada, S., Akiyoshi, T., and Miyazaki, T. (2010). Muscle weakness and neuromuscular junctions in aging and disease. Geriatr. Gerontol. Int. 10(Suppl. 1), S137-S147. doi: 10.1111/j.1447-0594.2010.00608.x

Slater, C. R. (2015). The functional organization of motor nerve terminals. Prog. Neurobiol. 134, 55-103. doi: 10.1016/j.pneurobio.2015.09.004

Slater, C. R. (2017). The structure of human neuromuscular junctions: some unanswered molecular questions. Int. J. Mol. Sci. 18:2183. doi: 10.3390/ ijms 18102183

Slater, C. R., Fawcett, P. R., Walls, T. J., Lyons, P. R., Bailey, S. J., Beeson, D., et al. (2006). Pre- and post-synaptic abnormalities associated with impaired neuromuscular transmission in a group of patients with 'limb-girdle myasthenia'. Brain 129(Pt 8), 2061-2076. doi: 10.1093/brain/awl200

Slater, C. R., Lyons, P. R., Walls, T. J., Fawcett, P. R., and Young, C. (1992). Structure and function of neuromuscular junctions in the vastus lateralis of man. A motor point biopsy study of two groups of patients. Brain 115(Pt 2), 451-478. doi: 10.1093/brain/115.2.451

Smith, D. O. (1988). Muscle-specific decrease in presynaptic calcium dependence and clearance during neuromuscular transmission in aged rats. J. Neurophysiol. 59, 1069-1082. doi: 10.1152/jn.1988.59.4.1069

Snyder-Warwick, A. K., Satoh, A., Santosa, K. B., Imai, S. I., and JablonkaShariff, A. (2018). Hypothalamic Sirtl protects terminal Schwann cells and neuromuscular junctions from age-related morphological changes. Aging Cell 17:e12776. doi: 10.1111/acel.12776

Stockinger, J., Maxwell, N., Shapiro, D., deCabo, R., and Valdez, G. (2017). Caloric restriction mimetics slow aging of neuromuscular synapses and muscle fibers. J. Gerontol. A Biol. Sci. Med. Sci. 73, 21-28. doi: 10.1093/gerona/glx023

Sudhof, T. C., and Rothman, J. E. (2009). Membrane fusion: grappling with SNARE and SM proteins. Science 323, 474-477. doi: 10.1126/science.1161748

Szule, J. A., Harlow, M. L., Jung, J. H., De-Miguel, F. F., Marshall, R. M., and McMahan, U. J. (2012). Regulation of synaptic vesicle docking by different classes of macromolecules in active zone material. PLoS One 7:e33333. doi: 10.1371/journal.pone. 0033333

Takamori, M., Maruta, T., and Komai, K. (2000). Lambert-Eaton myasthenic syndrome as an autoimmune calcium-channelopathy. Neurosci. Res. 36, 183191. doi: $10.1016 / \mathrm{s} 0168-0102(99) 00135-2$
Tomlinson, B. E., and Irving, D. (1977). The numbers of limb motor neurons in the human lumbosacral cord throughout life. J. Neurol. Sci. 34, 213-219. doi: $10.1016 / 0022-510 x(77) 90069-7$

Tsuji, S. (2006). Rene Couteaux (1909-1999) and the morphological identification of synapses. Biol. Cell 98, 503-509. doi: 10.1042/BC20050036

Tu, P. H., Raju, P., Robinson, K. A., Gurney, M. E., Trojanowski, J. Q., and Lee, V. M. (1996). Transgenic mice carrying a human mutant superoxide dismutase transgene develop neuronal cytoskeletal pathology resembling human amyotrophic lateral sclerosis lesions. Proc. Natl. Acad. Sci. U.S.A. 93, 3155-3160. doi: 10.1073/pnas.93.7.3155

Uchitel, O. D., Protti, D. A., Sanchez, V., Cherksey, B. D., Sugimori, M., and Llinas, R. (1992). P-type voltage-dependent calcium channel mediates presynaptic calcium influx and transmitter release in mammalian synapses. Proc. Natl. Acad. Sci. U.S.A. 89, 3330-3333. doi: 10.1073/pnas.89.8.3330

Ueta, R., Sugita, S., Minegishi, Y., Shimotoyodome, A., Ota, N., Ogiso, N., et al. (2020). DOK7 gene therapy enhances neuromuscular junction innervation and motor function in aged mice. iScience 23:101385. doi: 10.1016/j.isci.2020. 101385

Valdez, G., Tapia, J. C., Kang, H., Clemenson, G. D. Jr., Gage, F. H., Lichtman, J. W., et al. (2010). Attenuation of age-related changes in mouse neuromuscular synapses by caloric restriction and exercise. Proc. Natl. Acad. Sci. U.S.A. 107, 14863-14868. doi: 10.1073/pnas.1002220107

Valdez, G., Tapia, J. C., Lichtman, J. W., Fox, M. A., and Sanes, J. R. (2012). Shared resistance to aging and ALS in neuromuscular junctions of specific muscles. PLoS One 7:e34640. doi: 10.1371/journal.pone.0034640

Valenzuela, D. M., Stitt, T. N., DiStefano, P. S., Rojas, E., Mattsson, K., Compton, D. L., et al. (1995). Receptor tyrosine kinase specific for the skeletal muscle lineage: expression in embryonic muscle, at the neuromuscular junction, and after injury. Neuron 15, 573-584. doi: 10.1016/0896-6273(95)90146-9

Vandervoort, A. A. (2002). Aging of the human neuromuscular system. Muscle Nerve 25, 17-25. doi: 10.1002/mus.1215

Vincent, A., Lang, B., and Kleopa, K. A. (2006). Autoimmune channelopathies and related neurological disorders. Neuron 52, 123-138. doi: 10.1016/j.neuron.2006. 09.024

Walrond, J. P., and Reese, T. S. (1985). Structure of axon terminals and active zones at synapses on lizard twitch and tonic muscle fibers. J. Neurosci. 5, 1118-1131. doi: 10.1523/jneurosci.05-05-01118.1985

Warner, H. R., and Sierra, F. (2003). Models of accelerated ageing can be informative about the molecular mechanisms of ageing and/or age-related pathology. Mech. Ageing Dev. 124, 581-587. doi: 10.1016/s0047-6374(03) 00008-3

Webster, R. G. (2018). Animal models of the neuromuscular junction, vitally informative for understanding function and the molecular mechanisms of congenital myasthenic syndromes. Int. J. Mol. Sci. 19:1326. doi: 10.3390/ ijms 19051326

Weeda, G., Donker, I., de Wit, J., Morreau, H., Janssens, R., Vissers, C. J., et al. (1997). Disruption of mouse ERCC1 results in a novel repair syndrome with growth failure, nuclear abnormalities and senescence. Curr. Biol. 7, 427-439. doi: 10.1016/s0960-9822(06)00190-4

Weindruch, R., Walford, R. L., Fligiel, S., and Guthrie, D. (1986). The retardation of aging in mice by dietary restriction: longevity, cancer, immunity and lifetime energy intake. J. Nutr. 116, 641-654. doi: 10.1093/jn/116.4.641

Westerveld, A., Hoeijmakers, J. H., van Duin, M., de Wit, J., Odijk, H., Pastink, A., et al. (1984). Molecular cloning of a human DNA repair gene. Nature 310, 425-429. doi: 10.1038/310425a0

Wijshake, T., Malureanu, L. A., Baker, D. J., Jeganathan, K. B., van de Sluis, B., and van Deursen, J. M. (2012). Reduced life- and healthspan in mice carrying a mono-allelic BubR1 MVA mutation. PLoS Genet. 8:e1003138. doi: 10.1371/ journal.pgen. 1003138

Willadt, S., Nash, M., and Slater, C. (2018). Age-related changes in the structure and function of mammalian neuromuscular junctions. Ann. N. Y. Acad. Sci. 1412, 41-53. doi: 10.1111/nyas. 13521

Willadt, S., Nash, M., and Slater, C. R. (2016). Age-related fragmentation of the motor endplate is not associated with impaired neuromuscular transmission in the mouse diaphragm. Sci. Rep. 6:24849. doi: 10.1038/srep24849

Willig, K. I., Rizzoli, S. O., Westphal, V., Jahn, R., and Hell, S. W. (2006). STED microscopy reveals that synaptotagmin remains clustered after synaptic vesicle exocytosis. Nature 440, 935-939. doi: 10.1038/nature04592 
Wokke, J. H., Jennekens, F. G., van den Oord, C. J., Veldman, H., Smit, L. M., and Leppink, G. J. (1990). Morphological changes in the human end plate with age. J. Neurol. Sci. 95, 291-310. doi: 10.1016/0022-510x(90)90076-y

Wong, M., and Martin, L. J. (2010). Skeletal muscle-restricted expression of human SOD1 causes motor neuron degeneration in transgenic mice. Hum. Mol. Genet. 19, 2284-2302. doi: 10.1093/hmg/ddq106

Wood, S. J., and Slater, C. R. (2001). Safety factor at the neuromuscular junction. Prog. Neurobiol. 64, 393-429. doi: 10.1016/s0301-0082(00)00055-1

York, A. L., and Zheng, J. Q. (2017). Super-resolution microscopy reveals a nanoscale organization of acetylcholine receptors for trans-synaptic alignment at neuromuscular synapses. eNeuro 4. doi: 10.1523/ENEURO.0232-17.2017

Yuan, X., Klein, D., Kerscher, S., West, B. L., Weis, J., Katona, I., et al. (2018). Macrophage depletion ameliorates peripheral neuropathy in aging mice. J. Neurosci. 38, 4610-4620. doi: 10.1523/JNEUROSCI.3030-17.2018

Zampieri, S., Mammucari, C., Romanello, V., Barberi, L., Pietrangelo, L., Fusella, A., et al. (2016). Physical exercise in aging human skeletal muscle increases mitochondrial calcium uniporter expression levels and affects mitochondria dynamics. Physiol. Rep. 4:e13005. doi: 10.14814/phy2.13005

Zenker, M., Aigner, T., Wendler, O., Tralau, T., Muntefering, H., Fenski, R., et al. (2004). Human laminin beta2 deficiency causes congenital nephrosis with mesangial sclerosis and distinct eye abnormalities. Hum. Mol. Genet. 13, 2625-2632. doi: 10.1093/hmg/ddh284

Zhang, B., Tzartos, J. S., Belimezi, M., Ragheb, S., Bealmear, B., Lewis, R. A., et al. (2012). Autoantibodies to lipoprotein-related protein 4 in patients with double-seronegative myasthenia gravis. Arch. Neurol. 69, 445-451. doi: 10.1001/ archneurol.2011.2393
Zhang, C., Goto, N., Suzuki, M., and Ke, M. (1996). Age-related reductions in number and size of anterior horn cells at C6 level of the human spinal cord. Okajimas Folia Anat. Jpn. 73, 171-177. doi: 10.2535/ofaj1936.73. 4 4 171

Zhang, Y., Davis, C., Sakellariou, G. K., Shi, Y., Kayani, A. C., Pulliam, D., et al. (2013). CuZnSOD gene deletion targeted to skeletal muscle leads to loss of contractile force but does not cause muscle atrophy in adult mice. FASEB J. 27, 3536-3548. doi: 10.1096/fj.13-228130

Zhao, K., Shen, C., Li, L., Wu, H., Xing, G., Dong, Z., et al. (2018). Sarcoglycan alpha mitigates neuromuscular junction decline in aged mice by stabilizing LRP4. J. Neurosci. 38, 8860-8873. doi: 10.1523/JNEUROSCI.0860-18.2018

Zisimopoulou, P., Evangelakou, P., Tzartos, J., Lazaridis, K., Zouvelou, V., Mantegazza, R., et al. (2014). A comprehensive analysis of the epidemiology and clinical characteristics of anti-LRP4 in myasthenia gravis. J. Autoimmun. 52, 139-145. doi: 10.1016/j.jaut.2013.12.004

Conflict of Interest: The authors declare that the research was conducted in the absence of any commercial or financial relationships that could be construed as a potential conflict of interest.

Copyright $\odot 2020$ Badawi and Nishimune. This is an open-access article distributed under the terms of the Creative Commons Attribution License (CC BY). The use, distribution or reproduction in other forums is permitted, provided the original author(s) and the copyright owner(s) are credited and that the original publication in this journal is cited, in accordance with accepted academic practice. No use, distribution or reproduction is permitted which does not comply with these terms. 